\title{
TECHNOLOGY AND ORGANIZATION OF BLACK POTTERY PRODUCTION ON THE NORTH COAST OF PERU
}

\author{
Izumi Shimada \\ https://orcid.org/0000-0003-4595-2964 \\ Department of Anthropology, Southern Illinois University, Carbondale \\ ishimada@siu.edu \\ Ursel Wagner \\ Department of Physics, Munich Technical University, Munich, Germany \\ urwagner@gmx.de
}

\begin{abstract}
Not all «black» pottery was produced in the same manner just as their social and symbolic uses and reasons for production varied a good deal. Nor are many examples truly black. The Middle Sican culture (AD 900-1100) on the north coast of Peru distinguished itself with the perfection and large-scale production of black pottery made of fine paste. Based on our "holistic» study of a Middle Sican workshop (including experimental firing and detailed chemical analyses of both archaeological and experimental samples), we present a detailed characterization of the blackware production technology and organization. Our study revealed that the glossy Middle Sican blackware resulted from various factors including fring under strongly reducing conditions in small semi-closed kilns, an even carbon deposition on the vessel surface as well as penetration into the body, and the formation of graphite crystals on the well-burnished surface. Chimu reduced ware, in contrast, is typically made of coarser pastes, not as well burnished, and fired in relatively large "pit kilns" that did not permit a tight control over temperature and atmosphere. We infer that the prestige of the Middle Sican religion and its art together with the lustrous, truly black appearance of the pottery that had been rarely achieved before played an important role in establishing the popularity of black pottery not only in the Sican heartland but also much of the coastal Peru.
\end{abstract}

Keywords: black pottery, Sicán, holistic, archaeometry, experiments

\section{Resumen}

\section{TECNOLOGÍA Y ORGANIZACIÓN DE LA PRODUCCIÓN DE CERÁMICA NEGRA EN LA COSTA NORTE DE PERÚ}

No todas las cerámicas "negras" fueron producidas de la misma manera, sus aspectos sociales y simbólicos de usos y razones para la producción varía mucho. Tampoco son muchos los ejemplos de cerámica realmente negras. En realidad, no existen muchos ejemplos de cerámica verdaderamente negra. La cultura Sicán Medio (900-1100 d.C.) de la Costa Norte del Perú se distinguió por el perfeccionamiento y producción a gran escala de alfares negros hechos con pastas finas. Basados en nuestro estudio holistico de un taller alfarero Sicán Medio (que incluye experimentos de cocción y detallados análisis quimicos de muestras arqueológicas y experimentales), presentamos una caracterización detallada de la tecnología y organización de la producción de su cerámica negra. Nuestro estudio revela que la cerámica negra Sicán Medio resultó de varios factores incluyendo su cocción bajo condiciones fuertemente reductoras en hornos pequeños, semicerrados. La deposición uniforme de carbón sobre la superficie de las piezas, así como su penetración en el cuerpo mismo, y la formación de cristales de grafito en la superficie muy bien bruñida. En contraste, la cerámica reducida Chimú fue hecha típicamente empleando pastas más gruesas, con superficies no tan bien bruñidas, cocida en «hornos de hoyo", que no permitieron un control estricto de la temperatura y atmósfera de cocción. Inferimos que el prestigio de la 
religión Sicán Medio y de su arte, aunados a la apariencia lustrosa y realmente negra de su cerámica, una apariencia que raramente habia sido lograda en periodos anteriores, jugaron un rol importante en la instauración de la popularidad de la cerámica negra, discutida no solo en el dominio Sicán, sino en gran parte de la costa peruana.

Palabras clave: cerámicas negras, Sicán, holístico, arqueometría, experimentos

\section{Introduction}

In recent decades, archaeological studies of craft production and associated technology have deservingly expanded in scope and increased in number. Well-designed and implemented studies of craft production have the potential of being very informative and comprehensive cultural studies. It was with this belief that one of us (Shimada [ed.] 1994, 1998) edited two related volumes on technology and organization of pre-Hispanic Andean ceramic production. The books served as a vehicle for advocating studies centered on excavations of workshops, which afford primary data on the organization and technology of the craft production process, as well as on the identity of the producer and relationship(s) with the consumer/patron (see Shimada 2007; Shimada and Wagner 2007; Shimada and Craig 2013). Such excavations, however, should be holistic in scope and properly contextualized. In other words, we need to define the organization and technology of the entire craft production process from the acquisition of necessary ingredients to the functional capacity of finished products. Despite many decades of technical studies of pre-Hispanic Andean ceramics (e.g., Tello 1938; Digby 1948; Donnan 1965, 1992; Arnold 1972; Schaedel 1979; Purin 1983, 1985; Ravines and Villiger 1989; Carmichael 1990), there had been no comprehensive explication of the technological choices and the chaîne opératoire and that transforms raw materials into ceramic products or the social contexts in which such production occurred (e.g., Cresswell 1976; Lemonnier 1992, 1993; Leroi-Gourhan 1993; Sellet 1993; Shimada 2007; Shimada and Wagner 2007; Shimada and Craig 2013). This was due in part to the paucity of workshop excavations and interdisciplinary studies of associated technologies and their broader historical and social contexts. Studies of modern pottery making, technical analysis of finished products, and experimental replication and firing are informative, but, at the same time, have limitations and should not be relied upon solely. For example, modern pottery making may appear to have a similar chaîne opératoire, but the raw materials (e.g., clays, pigments, fuels) and usage, value and meaning of its products may be quite different from pre-Hispanic counterparts and vice versa (e.g., Mohr 1984-5; Bankes 1985; Cleland and Shimada 1994, 1998; Pozzi-Escot et al. 1998; Costin 2000; Sillar 2000; Arnold 2003; Stark 2003; Druc 2013). A given technology and its material, social, and ideological correlates do not seem to stay the same over centuries. Tourism and other external factors have impinged on what is considered to be age-old local pottery making, for example, paleteada vessels made in Mórrope, Lambayeque (cf. Collier 1959 and Bankes 1985). Pre-Hispanic equipment and associated techniques, such as small, semi-closed kilns (e.g., Shimada et al. 1994, 1998, 2007; Shimada and Wagner 2001, 2007) are no longer used by modern potters. Further, studies of finished products such as surface-collected sherds and whole vessels in museums are often constrained by skewed and/or partial representation of the total range and use context (typically funerary vessels) of products. Lastly, it is quite challenging to comprehend why certain ceramics were produced the way they were without the benefit of data and insights from a longterm or regional studies (e.g., stylistic trends and iconographic-symbolic choices) or the excavation ofworkshops and analysis of their remains; ceramics were influenced as much by the potter's skill, knowledge, creativity and motivation, as by the limitations and potential of raw materials, working conditions, and social (customers') expectations and values (Shimada 2007; Shimada and Wagner 2007; also see Costin 1991, 2000, 2001; Costin and Hagstrum 1995). 
In essence, the preceding discussion calls for contextualization of the production and its loci and attendant long-term, multipronged approach. Both are embodied in what Shimada calls "holistic approach". Suffice to note here that it and its applications have been described in depth elsewhere (Shimada 2007; Shimada and Merkel 1987; Shimada and Wagner 2007; Shimada and Craig 2013) and need not be repeated here.

The aim of this paper is to explicate our current understanding of the technology and organization of Middle Sicán (ca. AD 900-1100) black pottery production in the Lambayeque region of the north coast of Peru gained through the holistic approach described above. In addition, we provide a brief technological characterization of Chimú reduced ware ceramics to offer a basis for differentiating these two visually similar wares. We hope this paper also will inspire additional holistic studies of pre-Hispanic craft production. Specific questions that guided our study are also described below. Relevant research included (1) extensive excavations of a Middle Sicán ceramic workshop at Huaca Sialupe in 1999 and 2001, (2) ceramic firing experiments at the site in 2000 and at the modern workshop of José Sosa in Chulucanas in 2009 using a replica kiln and vessels modeled after those that we excavated at the site, and (3) a wide variety of complementary laboratory analyses of excavated and replica materials.

\section{Prehispanic Andean black pottery and diverse methods for achieving black finish}

Archaeologists commonly speak of "black pottery" as if all such pottery was produced in the same manner and/or has the same appearance. In reality, many examples are gray and may have been produced under different firing regimes. Gray and truly black (e.g., thoroughly and uniformly black) vessels were produced in different places and times in Andean prehistory but were most common on the northern coast of Peru and adjacent south and central coast of Ecuador. Potters of the Chorrera (coastal Ecuador), Cupisnique, and Chavín cultures produced technically high quality blackware all during the first half of the first millennium BCE. Blackwares of the latter two styles may have originated as emulation of rare and presumably prestigious, polished, anthracite vessels with low-relief ornamentation (Shimada and Wagner 2001, 2007). Later Guangala (coastal Ecuador), Maranga and Moche (aka Mochica) pottery also included similarly small percentages of finely burnished black pottery such as thin-walled bowls and effigy bottles, which were used primarily for elite and ceremonial purposes (e.g., Stumer 1957; Shimada 1994b: 191-195; 228). Moche blackware may represent an archaic revival of earlier Cupisnique. In general, however, high quality blackware production in pre-Middle Sicán era Andes was relatively limited in scale and intensity and it did not become a widespread, thriving practice.

Continuing on the preceding Moche and Early Sicán (AD 750/800-900) tradition of black ceramics, the Middle Sicán culture distinguished itself with advanced and innovative pyrotechnologies, particularly the perfection and large-scale production of black pottery and copper-arsenic alloys (e.g., Cleland and Shimada 1998; Shimada and Merkel 1991; Shimada and Craig 2013; Shimada and Wagner 2001). It is also characterized by the unprecedented production of precious sheet metals (e.g., Shimada 1994a,c, 1995; Shimada and Griffin 1994), the principle medium of the Sicán "aesthetic locus" (Maquet 1979, 1985). As discussed later, the Middle Sicán high valuation of shiny blackware may well reflect the high prestige commanded by lustrous precious metals. Middle Sicán black pottery, usually bearing simplified representations of the hallmark icons of either the Sicán Deity or its earthly alter ego, Sicán Lord (Fig. 1), was widely disseminated from Tumbes in the north to Pachacamac and the south-central coast in the south (e.g., Shimada 1990, 2000, 2014; Segura and Shimada 2014). It was emulated extensively by provincial potters whose products can be readily differentiated stylistically and technologically from those imported from the Sicán heartland, as seen in Table 1 and Figure 2. These differences suggest that the Middle Sicán blackware technology was either not shared or not mastered by local potters. 


\begin{tabular}{|c|c|c|c|c|c|}
\hline & $\begin{array}{c}\text { Manufacturing } \\
\text { technique }\end{array}$ & Forms & Finish & Paste & Firing \\
\hline $\begin{array}{l}\text { Middle } \\
\text { Sicán }\end{array}$ & $\begin{array}{l}\text { One or mul- } \\
\text { tiple pairs of } \\
\text { molds; thin } \\
\text { walls }\end{array}$ & $\begin{array}{l}\text { Symmetrical, } \\
\text { standardized } \\
\text { proportions of } \\
\text { various parts }\end{array}$ & $\begin{array}{l}\text { Highly po- } \\
\text { lished; often } \\
\text { has a metallic } \\
\text { sheen; evenly } \\
\text { black }\end{array}$ & $\begin{array}{l}\text { Fine paste } \\
\text { consisting of } \\
\text { prepared clay } \\
\text { (levigated) and } \\
\text { fine sand }\end{array}$ & $\begin{array}{l}\text { First in an } \\
\text { oxidizing at- } \\
\text { mosphere, then } \\
\text { in reducing } \\
\text { conditions at } \\
\text { ca. } 800^{\circ} \mathrm{C} \text { or } \\
\text { higher }\end{array}$ \\
\hline $\begin{array}{l}\text { Provincial } \\
\text { Sicán }\end{array}$ & $\begin{array}{l}\text { Modeled by } \\
\text { hand; relatively } \\
\text { thick walls }\end{array}$ & $\begin{array}{l}\text { Asymmetrical, } \\
\text { proportions } \\
\text { not } \\
\text { standardized }\end{array}$ & $\begin{array}{l}\text { Poorly polis- } \\
\text { hed; dull; often } \\
\text { not evenly } \\
\text { black }\end{array}$ & $\begin{array}{l}\text { Somewhat } \\
\text { coarser paste }\end{array}$ & Undefined \\
\hline
\end{tabular}

Table 1. Comparison of the Middle Sicán Black Pottery and Its Provincial Counterparts.

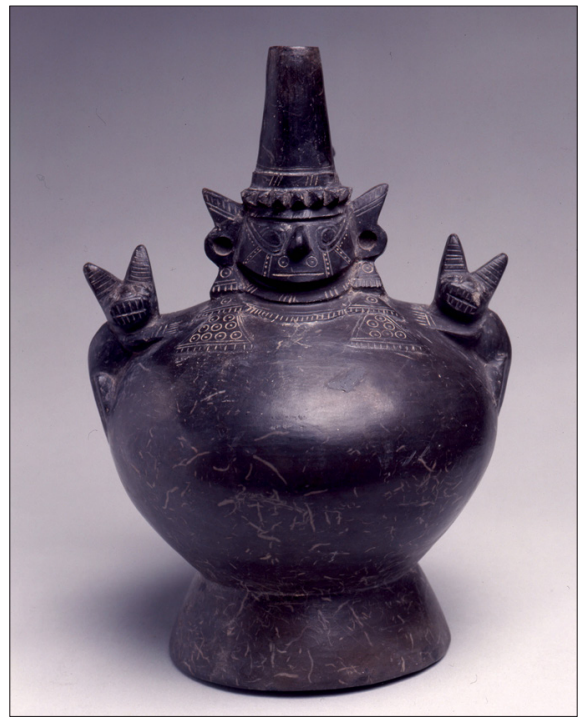

Figure 1. Example of a Middle Sicán black bottle with the Sican Deity icon decorating the base of the spout (Photo by Izumi Shimada).

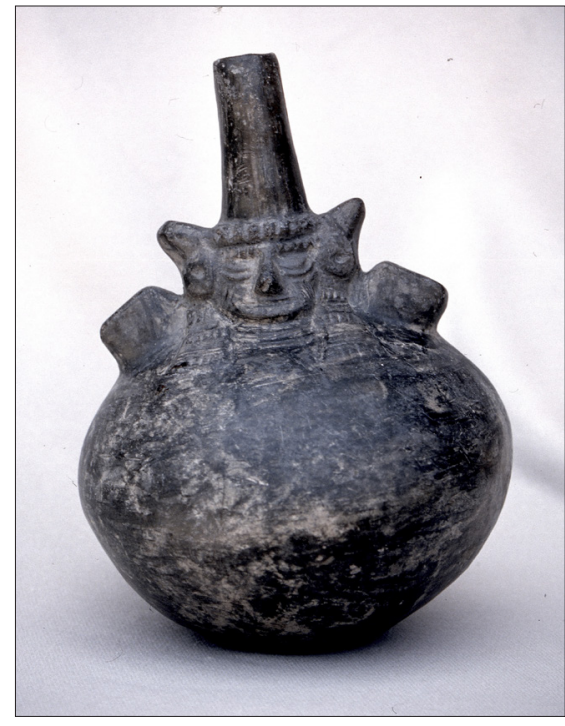

Figure 2. A provincial Sicán black bottle found in a burial excavated from the west face of the Huaca Cao Viejo mound, Huaca El Brujo. Compare it to the classic Sican bottle shown in Figure 1 (Photo by Izumi Shimada). 
The rapid spread of the technologically well-made and stylistically distinct Middle Sicán blackware brought about what Patricia Lyon (1991: 32) characterized as a "craze for monochrome [black or gray] pottery" along much of the Peruvian coast from ca. 1000 C.E. until the Spanish conquest. Although the Late Intermediate Period Chimú pottery is often characterized as mass-produced "blackware" (e.g., Bushnell 1957; Larco 1963, 1966; von Hagen 1964; Schjellerup 1986; de Lavalle 1988; Donnan 1992; Stone-Miller 1995), in reality, it is more often than not grayware. Truly black Chimú ceramics commonly have Sicán formal features such as pedestal base and tapering spouts (e.g., see plates on p. 105 and 107 in de Lavalle 1988; also Plates No. 46, 48, 49, 51 in Schjellerup 1986), suggesting production by Sicán artisans working for Chimú overlords following the conquest of the Sicán domain around 1375 CE (Shimada 2000, 2014).

There are various methods and reasons for producing black surface coloration on earthen pottery. Perhaps the simplest way to achieve this effect is to cover the pottery with a black slip prepared with charcoal powder. This method, however, has a major drawback as the charcoal is consumed during the firing, creating a "fugitive black" that rubs off easily and/or has a faded appearance. The San Pedro de Atacama polished blackware of northern Chile (first seven centuries CE) known for its meticulously burnished, thin walls and fine-grained granitic paste, is said to have achieved its color simply "by smoking or coating" (Gallardo et al. 2017: 253). A battery of archaeometric analyses have revealed that the black color on the late prehispanic Black-on-Red ceramics from the Quebrada de Humahuaca in the northwest Argentina derives from magnetite and microcrystalline graphite, but not manganese compounds (Acevedo et al. 2012). Firing regime involved, however, remains to be securely established. Williams (2010; also see Centeno et al. 2012; De La Fuente y Pérez 2018; Puente et al. 2017) does report a limited use of manganese oxide-based black paint (manganese oxide haussmanite, $\mathrm{Mn}_{3} \mathrm{O}_{4}$ ) also for late pre-Hispanic ceramics in the same northwestern Argentina. To date, use of manganese oxide-based slip to cover the entire vessel surface has yet been found in the Central Andes. In contrast, the sheen and uniform blackness on the famed Classic Greek (also known as Attic or Athenian) pottery of the mid- $6^{\text {th }}$ century to early $5^{\text {th }}$ century B.C.E. was permanent and the result of the formation of magnetite (a common black magnetic mineral consisting of iron oxide $\left[\mathrm{Fe}_{3} \mathrm{O}_{4}\right]$ ) in a painted ironrich slip layer under well-controlled, reducing firing conditions (Maniatis et al. 1993).

On the other hand, the shiny black coloration of the Central European Celtic (400-30 BC) pottery was a result of graphite flakes that were intentionally mixed into local clays (Wagner $e$ t al. 2005), which were fired in a reducing atmosphere at temperatures as high as $900^{\circ} \mathrm{C}$. The lustrous black-top finish on the predynastic Badari period bowls from Egypt in the University College London Petrie Collections (http://petriecat.museums.ucl.ac.uk/) were produced by yet another means. Refiring experiments and associated archaeometric analyses indicate that the bowls were fired inverted in a bed of finely crushed charcoal that produced a complete reduction (J.F. Merkel, 2011 personal communication).

Another ancient method for obtaining a black finish involved the deposition of carbon on and in the surface through the decomposition of soot or the pyrolysis of organic compounds introduced into the reducing kiln atmosphere, e.g., by firing with dried or conversely still moist dung, grass and/or firewood. Pyrolysis refers to the process of breaking down complex chemical substances into simpler substances through application of heat. This method requires that an effective reducing atmosphere be created and retained toward the end of the firing process by sealing the kiln or other firing structure.

With diverse methods available for achieving a black appearance on pottery as seen above, how did the Middle Sicán potters produce their blackware? How was its production organized in terms of spatial, temporal, material and human parameters? What motivated its large-scale production? How do the Middle Sicán solutions and rationale compare with those used for making other pre-Hispanic blackwares? These are the specific questions that we address in this paper. 


\section{The Huaca Sialupe workshop}

\subsection{Workshop setting and chronology}

Within the Middle Sicán heartland of the Lambayeque region, the presence of ceramic workshops has been inferred at Huaca del Pueblo Batán Grande and near the north base of Cerro Mauro, both in the mid-La Leche Valley, Pampa de Chaparrí that connects the upper portion of the La Leche and the neighboring Lambayeque Valley to the south (Frances Hayashida, personal communication, 2008), Vista Alegre just west of the town of Picsi, and Huaca La Pava near the town of Mochumi in the lower Lambayeque valley. In all these cases, except the first and the last, the inference is based on the presence of a handful of ceramic molds for forming a variety of relatively small vessels. In the case of Huaca del Pueblo Batán Grande, the 1983 excavation revealed a shallow, intensely reddened and clay-lined oval pit (ca. $2.5 \mathrm{~m} \mathrm{x} 2 \mathrm{~m}$ ) as well as modified sherd scrapers/sharpers. At Huaca La Pavas, excavation revealed many well-preserved matrices and mold fragments, stone burnishers, stamps and decorated paddles, as well as two adobe-lined "kilns" in the form of "figure 8" (Fernandez and Sánchez 2014). These kilns appear to be similar to those documented at Huaca Sialupe (see below; also Shimada et al. 1998). These two sites were both engaged in metalworking and pottery production.

The only workshop that was definitely involved in an intense blackware production, however, was the one at Huaca Sialupe. This workshop was situated in an agriculturally marginal area some 7 kilometers northwest of the city of Lambayeque where the adjacent La Leche and Lambayeque valleys imperceptibly merge together (Fig. 3). Quaternary coastal uplift has resulted not only in the formation of the extensive Sechura Dessert to the north and west, but also deposition of fine silt and clays brought to the area by the Motupe and La Leche Rivers from the northeast and east, respectively, particularly at times of El Niño-ENSO floods (Shimada 1981; Craig and Shimada 1986). While saline conditions from water scarcity and poor drainage limit agricultural production, the presence of readily available fine clays has enabled local inhabitants to make pottery, as has been the case, for instance in the nearby town of Mórrope (15 kilometers to the northwest) and surrounding hamlets in both historical and modern times (Collier 1959; Shimada 1976, 1994b; Bankes 1985; Cleland and Shimada 1998), and at Huaca Sialupe in the pre-Hispanic era. In other words, local ecological conditions have enabled and promoted pottery production as ceramic ecologists have argued (Arnold 2003). In fact, the 1996 survey that led to the discovery of the Sialupe workshop was guided by a careful consideration of local ecological conditions (Shimada 1999), illustrating the importance of a regional perspective in the holistic approach to ceramic production that we advocate here. The specific clues on the surface that indicated ceramic production at the site were a high density of diverse ceramic molds atop and around one of the principal mounds (Mound I) and notable concentrations of burnt soil, ash and charcoal bits on its downwind (north) side.

Our 1999 settlement survey covering an area of about $70 \mathrm{~km}^{2}$ around Huaca Sialupe revealed that only two among 30 previously unreported sites (one small, unnamed dune site and Huaca Pared-Uriarte) yielded diagnostic Middle Sicán ceramics. Huaca Pared-Uriarte is extensive (ca. 0.9 $\mathrm{km} \times 0.5 \mathrm{~km}$; Fig. 4) and its northern edge is only 300 meters south of Mound II of Huaca Sialupe. It has a high density of Middle Sicán utilitarian redware, suggesting intense domestic occupation. At the northeast edge of the site, there is a walled-in rectangular plaza (ca. $50 \mathrm{~m}$ x $60 \mathrm{~m}$ ) bordered on three sides by major adobe platform mounds. The overall architectural layout and composition of this plaza complex are reminiscent of the Great Plaza complex at the Middle Sicán capital of Sicán, about 22 kilometers to the northeast. Thus, Huaca Pared-Uriarte was hypothesized to have been the local Middle Sicán population and political-religious center that also directed the production of fine serving and ceremonial pottery at the nearby Huaca Sialupe workshop and regional distribution of products (Rospigliosi 2007). 
Figure 3. Map showing the locations of the archaeological sites of Huaca Sialupe, Huaca Pared-Uriarte, Huaca Chotuna, and Sicán as well as the modern settlement of Mórrope and Lambayeque (Drawing by Kayeleigh Sharp).

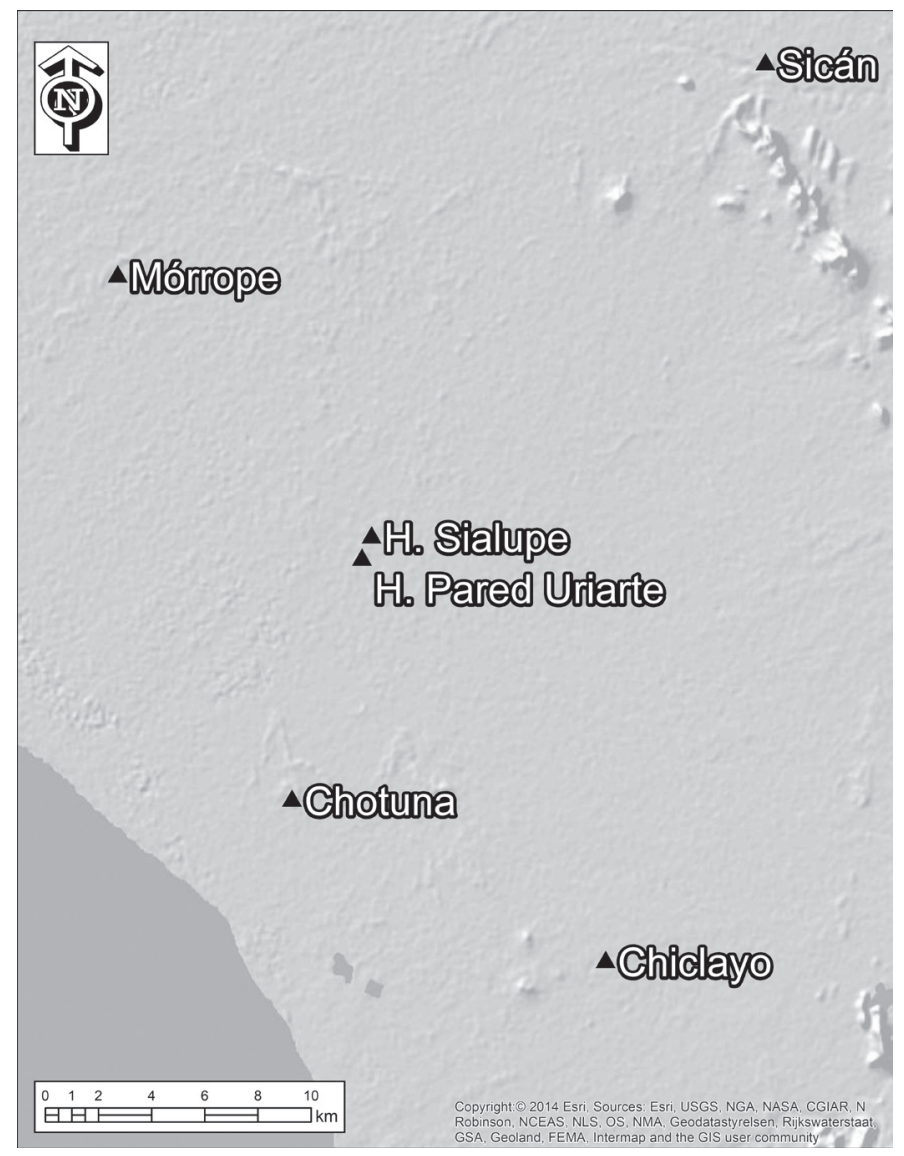

The site of Huaca Sialupe (Fig. 4) consists of four low mounds that together cover a roughly rectangular area $250 \mathrm{~m}$ East-West by $400 \mathrm{~m}$ North-South. The Middle Sicán workshop and associated cemetery occupied the basal levels of a stabilized sand dune that is oriented N-S and shaped like a figure-8 (designated as Mound I and II). Late Sicán, Chimú and Chimú-Inka occupations overlay the workshop. The remaining mounds appear to have been the loci of later (Late Sicán and Chimú) workshop and habitational zones, according to surface remains. Although we suspect that Mound V was most likely the residential area of those associated with the Middle Sicán workshop, the presence of modern houses does not allow testing of this inference. The placement of a workshop atop Mounds I and II that are oriented N-S along the direction of the pervasive wind off the Pacific is logical, as good ventilation is crucial to drying and firing of ceramics and heating of metalworking furnaces. The wind also removes noxious smoke away from the workshop as well as the inferred residences on Mound V.

The Middle Sicán multi-craft workshop at Huaca Sialupe, in reality, was involved simultaneously in production of relatively small utilitarian and decorated fine pottery (including what is commonly called huaco rey - single-spout bottle; Figure 1) with pedestal base) and relatively small metal objects. Besides utilitarian items such as needles, spoons, and chisels that were made from arsenical copper, a small number of gold and silver alloy ornaments were produced at the workshop. The metalworking component of the workshop and its technological and social relationships with ceramic production are discussed elsewhere (Shimada and Wagner 2001, 2007; Shimada et al. 2003a, 2007; Goldstein and Shimada 2007, 2010). 


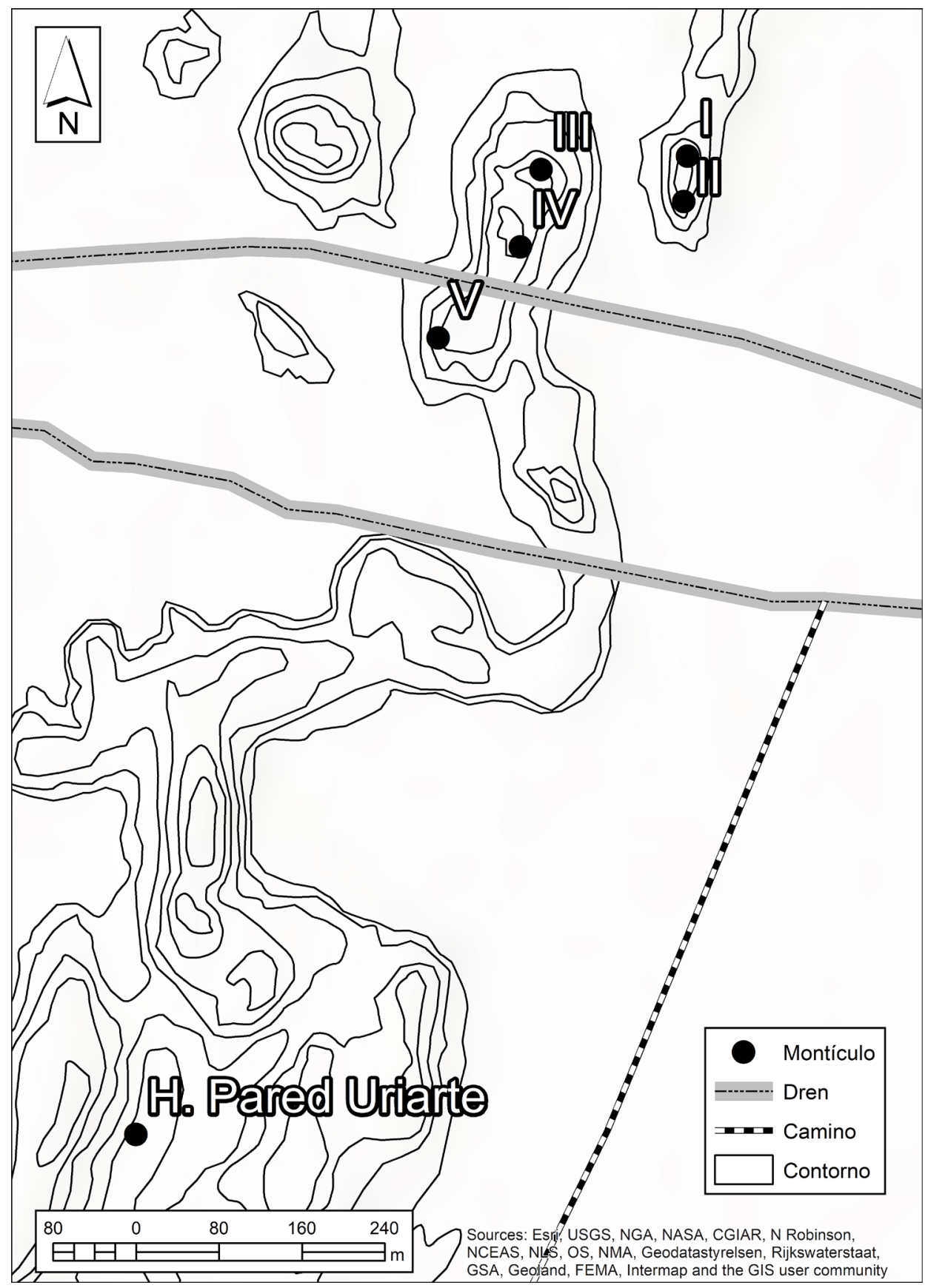

Figure 4. The sites of Huaca Sialupe and Pared-Uriate and their surroundings (Drawing by Kayeleigh Sharp). 
Our excavations in 1999 and 2001 revealed that the workshop was built directly over the sterile sand dune and went through many minor and at least two major remodelings since its establishment ca. 950-1000 CE. Accordingly, occupation of the workshop is divided into three phases that are together estimated to have spanned fewer than 100 years (Shimada and Wagner 2007). Deeply buried remains of the earliest phase, $\mathrm{C}$, have been exposed only partially and their overall layout remains poorly known. The Middle phase, $\mathrm{B}$, corresponds to occupation immediately preceding a severe El Niño-ENSO rainfall episode tentatively dated ca. $1050 \mathrm{CE}$. The associated rains not only heavily damaged quincha (wattle-daub) constructions (e.g., a collapsed walls and roofs and melted plaster), but also appear to have occasioned temporary abandonment (up to a few years) of the workshop as suggested by the presence of patches of fluvial deposits and various stumps of young trees (ca. 1-2 cm diameter) (Shimada et al. 2018). A wide variety of ceramic production-related items such as molds and unfired vessels were thus abandoned on the floor. In this paper, we focus our attention on the best documented Phase B. The late phase, A, corresponds to a brief occupation following the El Niño-ENSO event before the workshop was permanently abandoned sometime between 1050 and $1100 \mathrm{CE}$.

\subsection{Physical and activity organization of the workshop}

The preserved remains of the Phase B workshop cover an estimated $1750 \mathrm{~m}^{2}$ (maximum dimensions of ca. $70 \mathrm{~m} \mathrm{~N}-\mathrm{S} \times 28 \mathrm{~m} \mathrm{E}-\mathrm{W})$. Our excavations exposed about 35\% of this workshop, that is, $480 \mathrm{~m}^{2}(16 \mathrm{~m} \mathrm{x} 30 \mathrm{~m})$ and $115 \mathrm{~m}^{2}(10 \mathrm{~m} \mathrm{x} 11.5 \mathrm{~m})$ of continuous workshop area at Mounds I and II, respectively. They revealed (1) that during Phase B there were two distinct groups of ceramic kilns situated at the downwind end of the workshop (e.g. in the northern and northwestern sectors of Mound I; Fig. 5), (2) that during Phase A, one of the Phase B ceramic firing areas (e.g., Room 39) became a major copper-and gold-alloy working area (e.g., Room 18) with at least three furnaces, and (3) that throughout the Middle Sicán occupation, the upwind end of the workshop (e.g., southern half of Mound II) was used exclusively for metalworking with at least five furnaces. The two foci of metalworking were some $45 \mathrm{~m}$ apart with much of the intermediate space occupied by quincha rooms used for pottery making.

The sand-covered west slope of Mound I was used as a cemetery during the Middle Sicán period presumably by those associated with the adjacent workshop. However, the extended burial position, placement of copper objects in the mouths of the deceased, and the conspicuous absence of pottery and other grave goods bearing Sicán icons all suggest that the local population consciously chose their traditional Moche ethnic funerary customs and symbolism rather than accepting the intrusive Sicán counterparts (Klaus 2003; Klaus and Shimada 2003). Thus, we infer that the Sialupe potters were local Moche artisans who were co-opted to serve the intrusive Sicán and produced diagnostic Middle Sicán finewares as well as Mochicoid vessels (Rospigliosi 2007; Shimada and Wagner 2007).

During much of, if not the entire, span of Middle Sicán occupation, the workshop was engaged primarily in intense production of relatively small, decorated black-and red-ware ceramics formed with molds, with concurrent smithing of copper arsenic alloys and gold alloys (Shimada et al. 2007; Shimada and Wagner 2001, 2007). The distribution and composition of pottery making remains, together with the architectural/access pattern (for detailed description, see Shimada and Wagner 2007) suggest the following:

1. The central sector of Mound I (Fig. 5), particularly Rooms 23, 25, and 35, were engaged in the formation and finishing of pottery throughout all three occupational phases.

2. Rooms 10 and 13 on the east side were used for making small mold-made ceramic appliqués as well as for cutting and shaping small metal objects. 


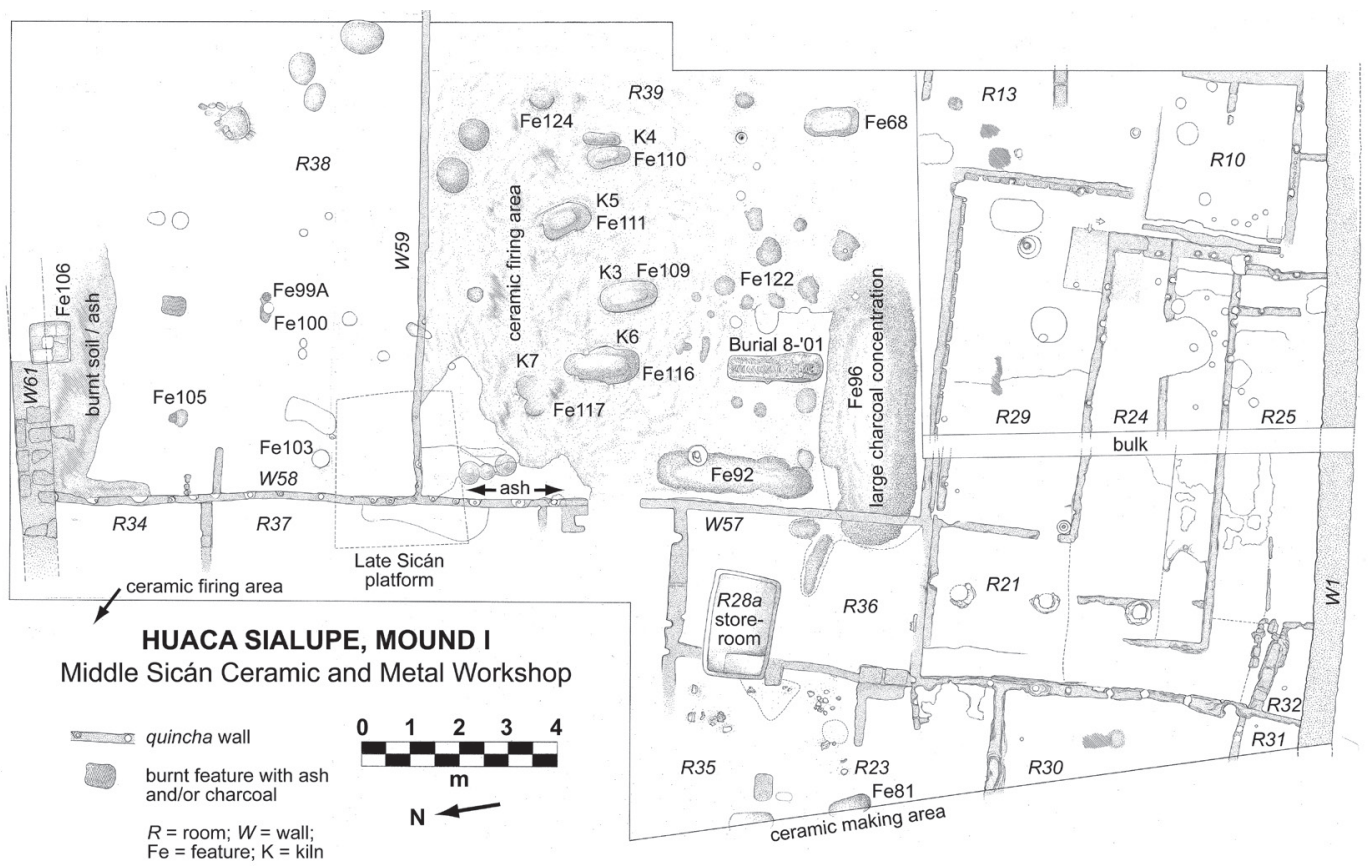

Figure 5. Phase B architecture and associated floor features in Mound I, Huaca Sialupe (Drawing by César Samillán and Izumi Shimada).

3. While the two potters or groups of potters in Rooms 23 and 25 produced a similar array of products, primarily a variety of bowls and bottles, their technical and stylistic details differed. Variation is seen, for example, in the number of molds used to form the same type of bottle (Fig. 6) and details of the representations of the Sicán Deity, both, pointing to a considerable amount of creative autonomy enjoyed by the artisans.

4. Room 24 served as setting for the production supervisor and/or communal resting area for artisans, while the spacious floor of adjacent Room 29 served as a pottery drying area. Both Room 24 and 29 were centrally situated, accessible from the east and west, and devoid of pottery-making items. Room 24 instead had a long bench and two jars set into the floor each covered by a serving bowl.

5. The spacious, largely un-roofed areas at the north end of Mound I were used for pottery firing and storage of necessary fuels.

The Phase B Rooms 23, 25, and 35 yielded diverse and numerous ceramic production-related remains, including apportioned clay lumps each wrapped in a coarse cotton cloth, use-altered hematite lumps (pigment), potter's plate fragments, shapers/scrapers made of sherds with smooth, curved edges, and many complete and fragmentary molds and matrices (aka positives) for making molds. A total of over 2,000 molds and 100 matrices, both whole and fragmentary, were recovered from primary and secondary contexts in our excavations in 1999 and 2001. Matrices are distinguished from products by their much thicker wall construction, smooth finish, and medial, top-tobottom incisions. The groove was made in order to insert a string used later to separate the halves of vertical molds. The matrix was then covered by a layer of clay leaving two ends of the string hanging out. Once the clay becomes leather-hard, the string was pulled, cutting the clay covering the matrix into the two halves of a mold. Molds were represented predominantly by broken pieces of vertical pairs for forming parts of vessels or entire vessels (Fig. 7). Importantly, vessel molds of both Middle Sicán and Mochicoid styles were found commingled on the same floor indicating 

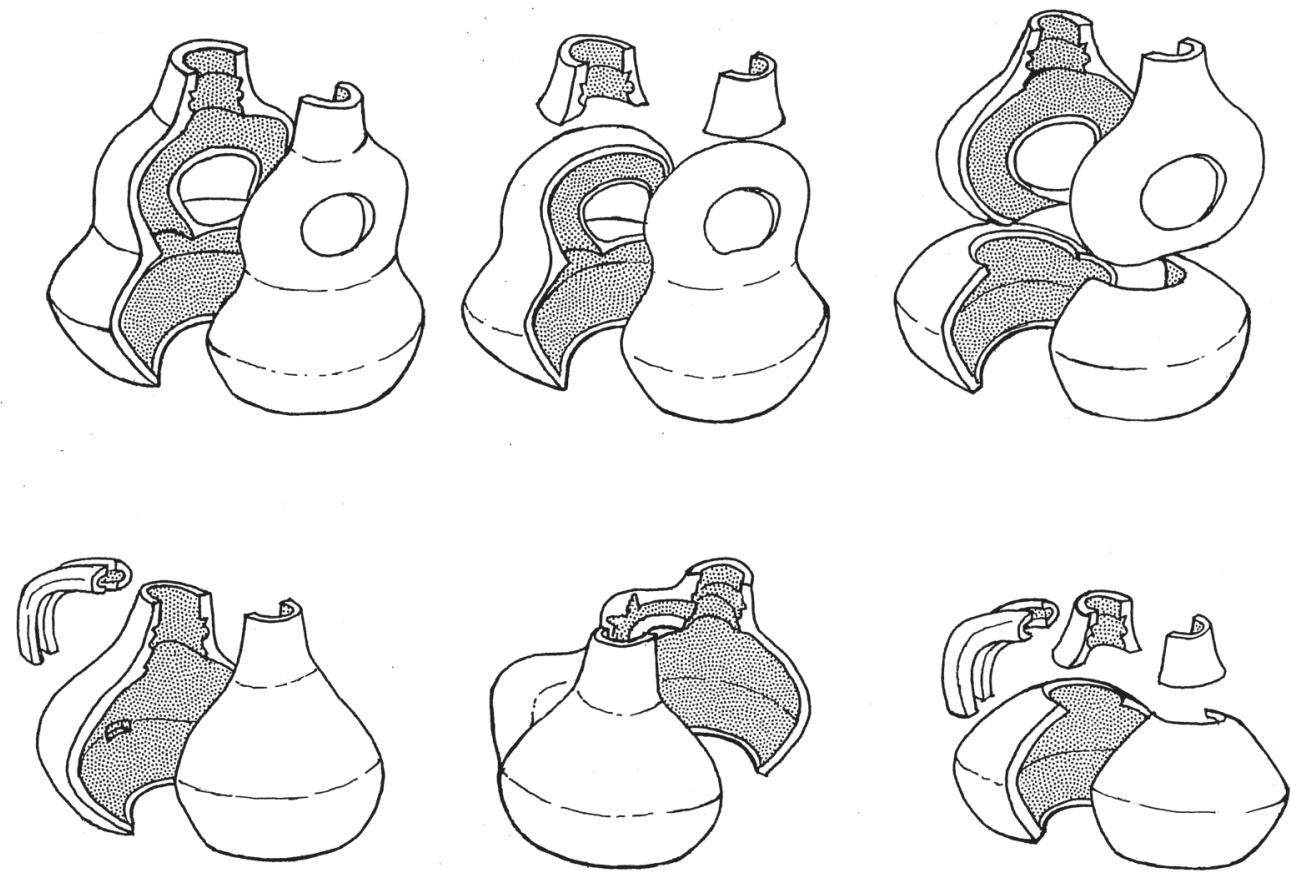

Figure 6. Three different ways of forming the stirrup-spout and single-spout bottles used at the Huaca Sialupe workshop (Drawing by Izumi Shimada).

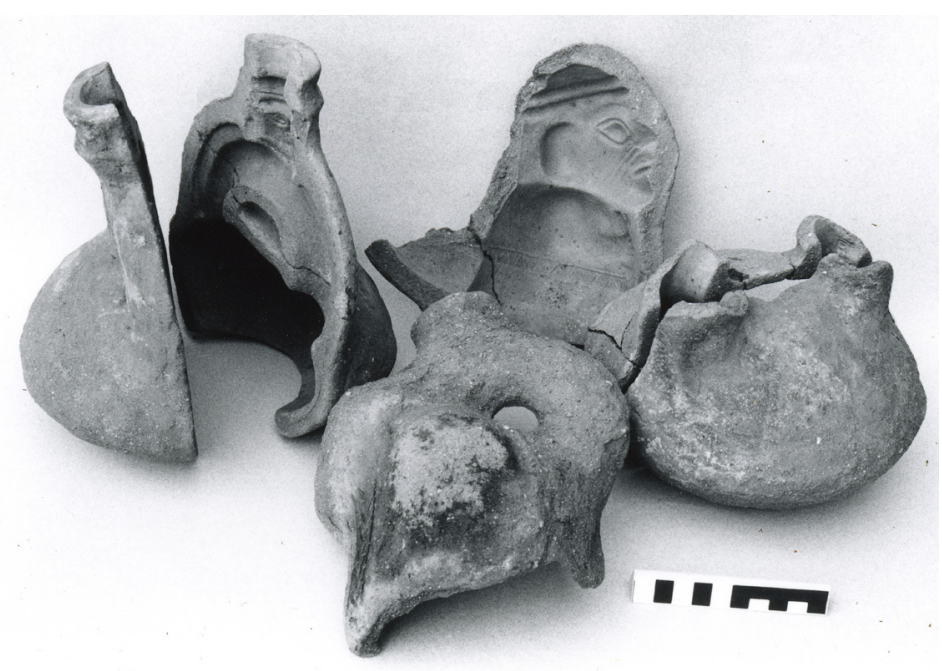

Figure 7. Examples of paired vertical molds for making complete Middle Sicán stirrup-spout bottles. All excavated at Mound I, Huaca Sialupe (Photo by Izumi Shimada). 
that both styles were concurrently produced. Intact pairs and relatively small, single molds for making figurines and appliqué pieces were also recovered. Vessel forms represented in recovered molds agree well with sherds found in fills and are dominated by bowls, dishes, plates and bottles, especially stirrup-spout, and single- and double-spout bottles, and to a lesser extent, face-neck jars and canteens (Rospigliosi 2007; Taylor 2002; Taylor and Shimada 2001). Less common in both molds and sherds are figurines, zoomorphic and anthropomorphic effigy bottles, double-chambered bottles, flaring cups or beakers, human- and animal-head appliqué pieces, and hollow Sicán Deity heads that probably served as architectural ornaments.

In Room 25, a vertical mold pair for making double-chambered bottles was found with prepared clay pressed onto the interior surface. On the floor near the molds were a small pile each of coarse sand and a beige-colored, homogenous, very fine clay powder that is inferred to have been used for making a cream-colored slip.

Room 23 contained not only some dozen whole and large fragmentary molds mainly for stirrup-spout and effigy bottles and two clusters of unfired flaring bowls, but also four disk-shaped, prepared and apportioned clay lumps (Fig. 8) and two broken porrones, large ovoid storage urns with tapering bottom and with or without short, slightly constricted neck, each set into a conical pit in the floor. The lower interior of one porrón was coated with fine clay and further down toward the bottom with coarser silt-sand mixture. This vessel, we suspect, was used to levigate clay(s) by placing crushed or ground clay in water, stirring the mixture, and letting coarser, heavier particles separate from finer, lighter particles. Typically, the portion containing the latter is decanted and then dried. Through this simple process, the potter can obtain a fine, homogenous clay mixture that is easy to manipulate and fire as modern Chulucanas potters in the upper Piura valley do.

The above interpretation concerning the porrón is supported by the results of various archaeometric analyses that are integral to our holistic approach. The highly homogenous particle size $(\geq 0.1$ $\mathrm{mm})$, mineral content and texture documented by thin-section petrography and x-ray diffraction analysis (hereafter TSP and XRD, respectively; Shimada et al. 2003b, c; Wagner et al. 2014) argue that the recovered four disk-shaped lumps resulted from intentional levigation of naturally occurring clays. It is likely that the two larger clay pieces were used in making relatively small, finely decorated vessels such as shallow bowls and bottles. This inference is based not only on the type and amount of fine sand inclusions found in both the clay pieces and bottles produced at the workshop, but also on the sizes of the clay pieces (between 160 to $288 \mathrm{~g}$ in weight) that preserved imprints of the plain-weave cloth that tightly wrapped them. Clearly, Middle Sicán potters apportioned the prepared clays with specific products in mind and carefully wrapped them with wet cloths to keep them moist. José Sosa, a professional potter from Chulucanas, prepared dozens of replicated Middle Sicán vessels in preparation for our pottery firing experiment in 2000 (see below for details). The amounts of the levigated local clay with fine sand inclusions he prepared and used in making shallow bowls and bottles (single-spout and double-spout) match well with the small and large prepared clay pieces excavated in Room 23 (taking into account differences between the moisture content of modern and the ancient clay mixtures).

The archaeometric analyses mentioned above and neutron activation analysis (hereafter NAA) further revealed that, in terms of mineralogical and chemical composition, (1) samples of these clay pieces, unfired vessels, molds, matrices, and wasters are all quite homogenous, and (2) indistinguishable from local clay (extracted from a local adobería, pit for extracting clay for making adobes, and the bottom of a local canal) and the clays found in adobe bricks and mortar used in the Middle Sicán architecture at Mound I (Shimada et al. 2003a, b, c). Rather, differences among these products are largely a matter of variation in amount and particle size of inclusions mixed into the clay. Inclusions constitute between 20 and $35 \%$ of the total volume and are mainly quartz (homogenous with slightly rounded edges) and plagioclase. Fine vessels such as bottles have fine sand inclusions that constitute ca. $20-25 \%$ of total volume of their paste, while matrices and molds have coarser 
Figure 8. Prepared clay pieces found together in Room 23. Note the impression of plain-weave cloth, indicating that they were wrapped with wet cloth to keep them moist (Photo by Izumi Shimada).

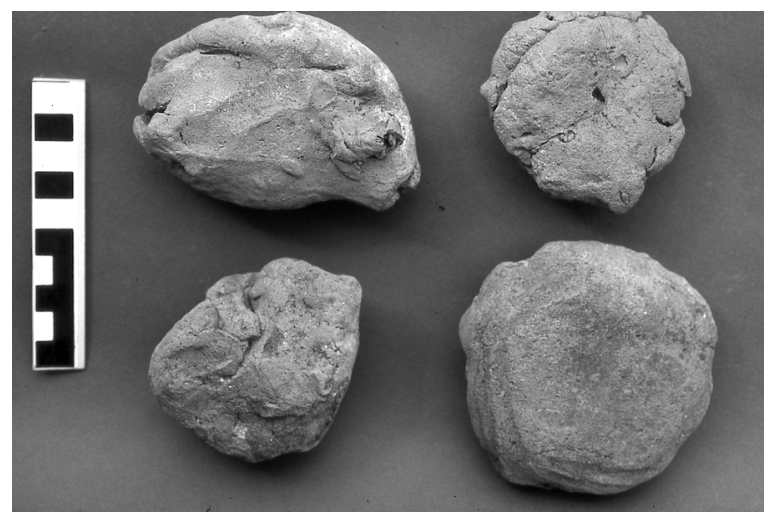

sand inclusions and a corresponding value of ca. 30\%. We can conclude that the Huaca Sialupe potters made their pottery as well as corresponding matrices and molds with readily available local clays and that fine vessels such as black bottles were prepared with levigated local clay.

\section{Ceramic Kilns at Huaca Sialupe}

Critical to our discussion of blackware production is the northern area of the workshop. Along the very northern edge of the mound, many lenses and pits containing mixtures of ash, charcoal bits, and burnt soil reach down to sterile sand 120 centimeters to 150 centimeters below surface. These deposits evidently represent dumped refuse from the nearby kilns and furnaces.

Room 39 (R-39) in this northern sector was a spacious (ca. 10.5 m north-south $\mathrm{x}$ at least 7.5 m east-west; Fig. 5), largely walled-in, unroofed area that was intensely used for blackware firing in Phase B. Only the southern margin of this area was roofed according to the locations of identified wooden post remains. The north, south and west sides of R-39 were clearly demarcated by quincha walls. The east side of the room has not been defined. Thick but localized lenses of blackish soil rich in ash and charcoal bits as well as black sherds were concentrated along the south edge of R-39. The two shallow but extensive concentrations of ash and charcoal bits (Features 92 and 96; Fig. 5; dimensions of $3.15 \mathrm{~m} \times 0.75 \mathrm{~m}$ and $0.12 \mathrm{~m}$ deep and $5.15 \mathrm{~m} \mathrm{x} 1.9 \mathrm{~m}$ and $0.18 \mathrm{~m}$ deep, respectively) in the southwest corner of R-39 are believed to represent areas for preheating pottery vessels to be charged into the nearby kilns. The superficial dull, orangish heat-discoloration seen below the ash and charcoal concentration and the small twig and branch-sized charcoal bits suggest only a relatively low and ephemeral heat generated here. Modern potters who utilize primitive kilns or even simpler firing structures on the north coast of Peru (e.g., in Mórrope, Chulucanas, and Simbilá; Cleland and Shimada 1998: 118-119) and elsewhere in the world commonly preheat their vessels up to ca. $100^{\circ} \mathrm{C}$ to reduce their moisture content, the buildup of steam and the overall risk of thermal shock when vessels are subjected to a rapid rise in temperature in the kiln (e.g., Rice 1987: 152-153; Reina and Hill 1978: 39; Ravines and Villiger 1989).

Three oval kilns (K-3 to 5; Features 109-111; Fig. 5) spaced roughly $1 \mathrm{~m}$ apart from each other, the basal portion of another kiln (K-6; Feature 116), and other intensely burnt features were found built on an earthen floor thoroughly blackened with charcoal powder and ash (Fig. 9). A smaller, burnt, oval structure that partially overlies K-4 and another shallow pit north of K-6 may well be poorly preserved bottoms of additional kilns (Fig. 5). These structures are oval to teardrop shaped ("figure-8 shaped"), shallow pits lined with clay-sand mixture, with the larger end (the firing chamber where vessels were placed) oriented downwind to the north. The bottoms are ca. 10-20 centimeters below floor level and measure ca. 100 to 150 centimeters in length and 50 to 70 centimeters in width. All were thoroughly coated with charcoal bits and powder and one had 


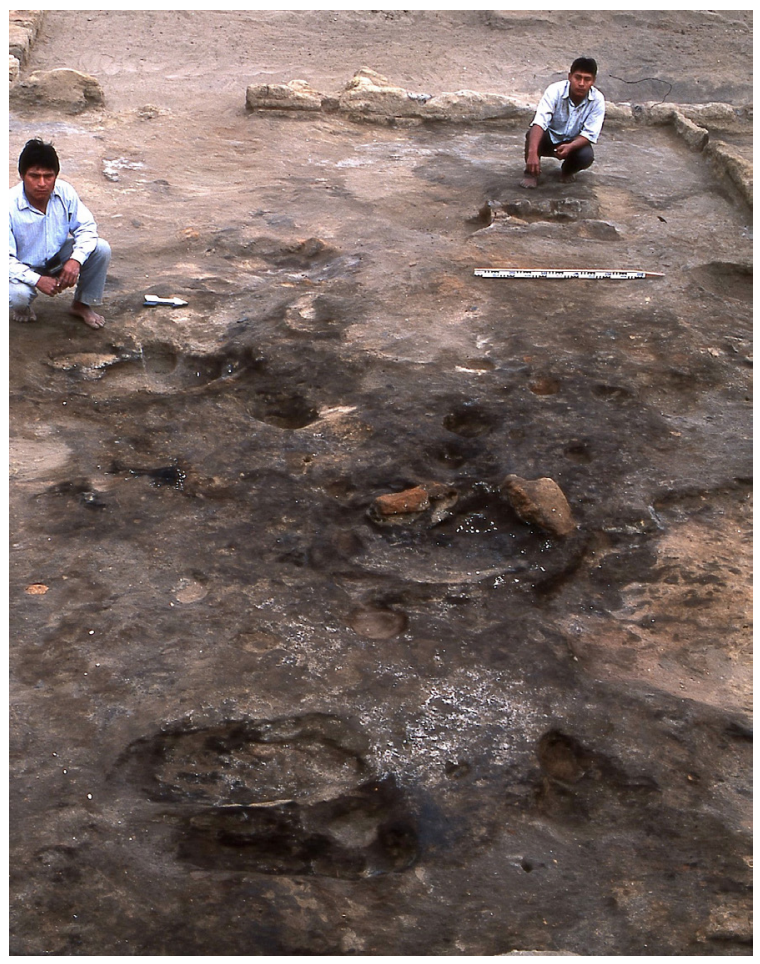

Figure 9. A view of Room 39 with evenly spaced kilns and blackened floor (Photo by Izumi Shimada).

over 50 fine black pottery fragments (e.g., stirrup-spout bottles and jars) mixed in with compacted charcoal remains. Heat-discolored, collapsed lining fragments found inside indicate that the kilns originally had incurving, refractory walls to create a dome-like firing chamber as seen in the reconstruction drawing (Fig.10).

Their basic design and overall size and shape closely resemble the 3000-year old Formative kilns we excavated earlier along the bottom of the abandoned Pomac Canal some 25 kilometers to the northeast (in the Pomac National Historical and Ecological Sanctuary in the mid-La Leche Valley; Shimada 1997, 2019; Shimada et al. 1994, 1998). This type of small, keyhole or figure 8-shaped, semi-closed, updraft kiln has been documented in Pomac as persisting at least up to the Late Gallinazo-Moche III period, ca. AD 350-400. The Huaca Sialupe excavations show that the same basic kiln-design persisted into the Middle Sicán period.

During Phases B and C, the adjacent northwestern portion of Mound I was used for pre-heating and oxidizing pottery firing. Built into an uneven, compacted occupational surface were the remains of at least three oval kilns and quantities of ash and charcoal (Fig. 11). One inferred kiln consists of five intensely oxidized adobe bricks surrounding an oval trough lined with fine clay. The trough is estimated to have originally been ca. 125 centimeters long, 70 centimeters wide and at least 30 centimeters deep. The in situ kiln wall still stands ca. 30 centimeters. Another inferred kiln (estimated 125 centimeters long, 55-60 centimeters wide and at least 30 centimeters deep) is situated ca. 1.5 meters to the east of the first. Both kilns appear to have resembled a longitudinally sliced, flattened egg in shape; i.e., a flat bottom and curving sidewalls. Although the upper portion of the kiln was not preserved, the shape of the sidewalls suggests a dome-like structure above the firing chamber.

Distribution of burnt adobe brick fragments and clay lumps suggest that there may well have been two more kilns. Given that the preserved remains of kilns are all highly oxidized, it is suspected that the kilns in the northwestern portion of Mound I were all employed in oxidizing 

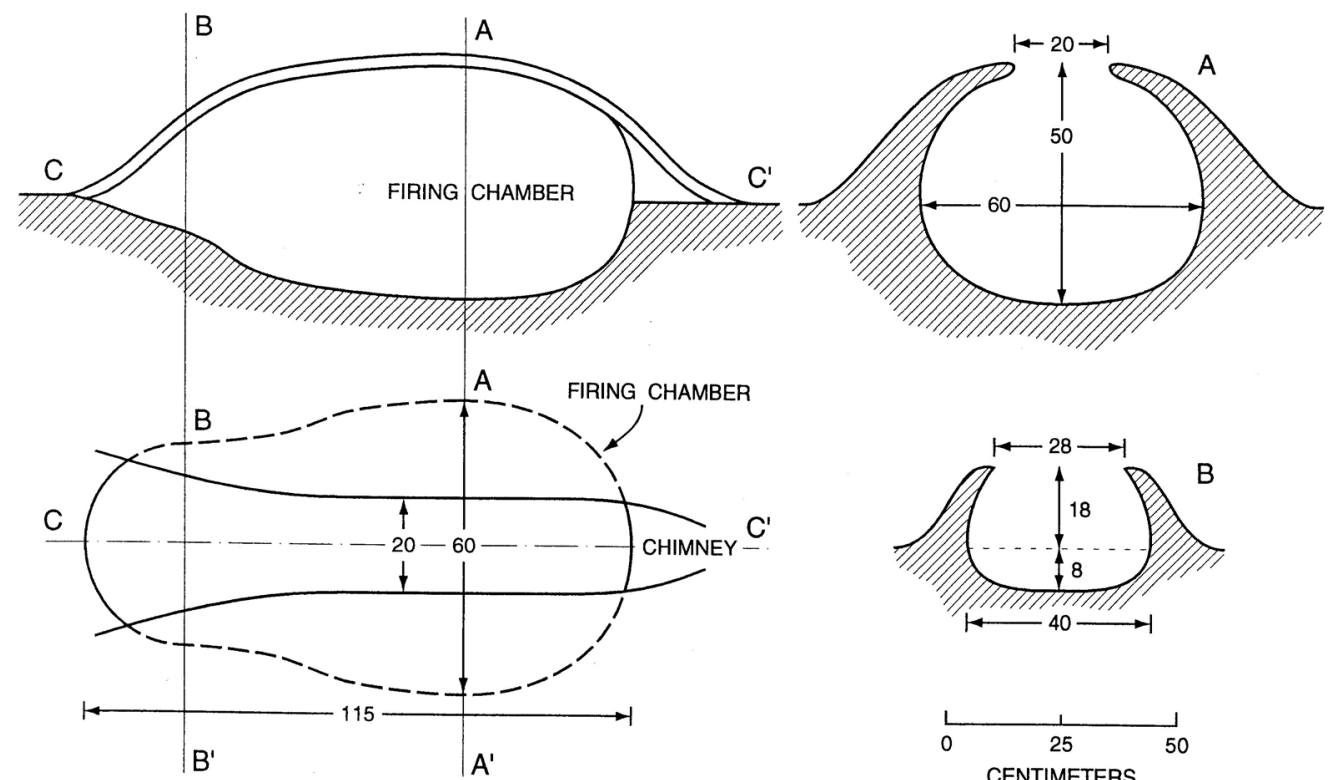

Figure 10. Plan and sectional views of a reconstructed Middle Sicán ceramic kiln believed to have been used for firing black pottery. The reconstruction is based on measurements and observations of kilns excavated in Room 39 (Drawing by Izumi Shimada).

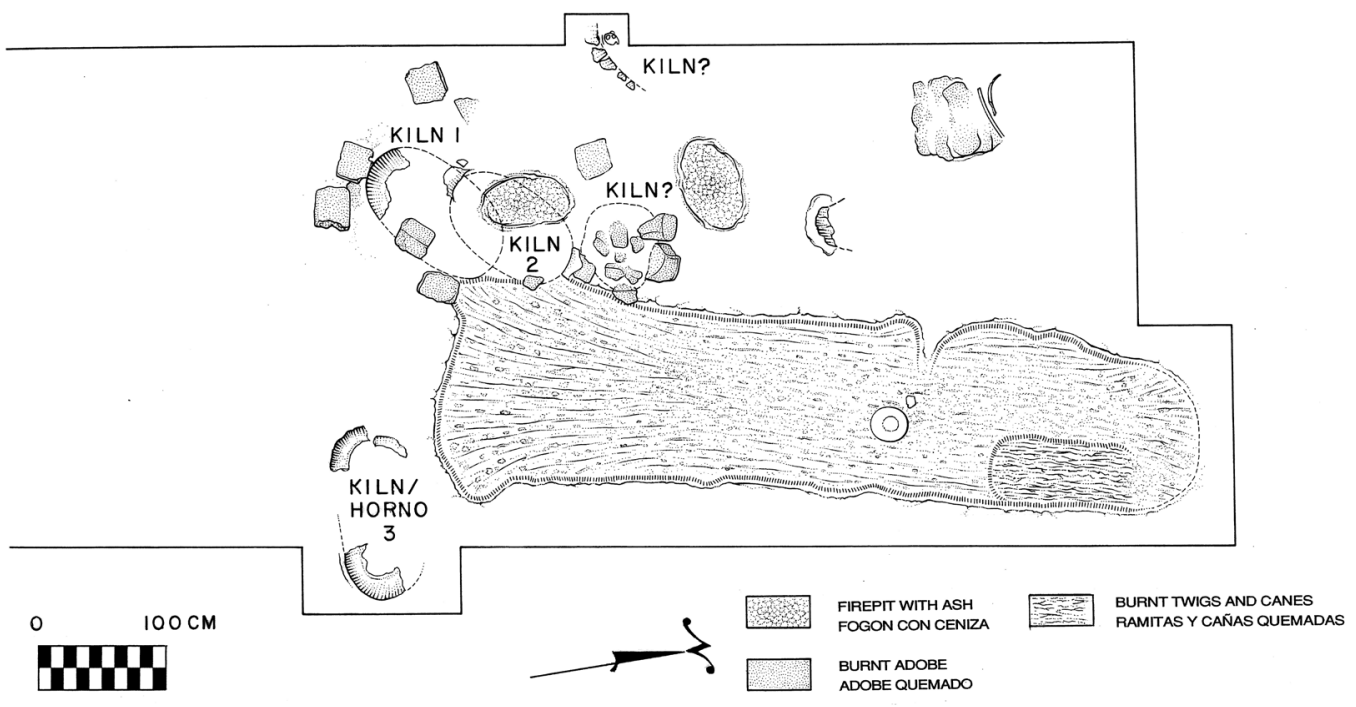

\section{MOUND I, NORTH AREA MONTICULO I, AREA NORTE}

Figure 11. Relative locations and forms of the kilns believed to have been used in oxidized firing and an associated pre-heating area (Drawing by César Samillán and Izumi Shimada). 
firing of ceramics. It is also worth noting that the inferred kilns are situated very close to and at the downwind end of an elongated deposit of ash and charcoal (ca. $5.5 \mathrm{~m} \mathrm{x} 1.5 \mathrm{~m}$ and $0.1 \mathrm{~m}$ in thickness) that is believed to have been used in preheating ceramic vessels before they were placed inside the kiln (Fig. 11). The charcoal-ash concentration consisted primarily of carbonized twigs and cane that were laid out systematically along a north-south axis in a thin, even layer. These fuels would have been readily available, would burn quickly to produce small charcoal bits and hot ash well suited for preheating pottery.

Between the two spatially segregated firing areas described above and accessible from both is a spacious walled-in area, Room 37, with an earthen floor devoid of any artifacts or features on the floor. The area may have been used for storing fired vessels or, conversely, those waiting to be fired. The organization of activities described above seems logical in terms of the wind direction, manufacturing processes and related practical concerns. For example, activities involving the use of fire would be expected to have been concentrated in the downwind northern portion of Mound I to keep bulky fuels as well as unpleasant smoke and debris away from the rest of the workshop. This placement also dovetails well with firing being one of the last stages of the ceramic production process.

\section{Data and insights from the ceramic firing experiments and related archaeometric analysis}

Answers to questions concerning the critical firing of black pottery were partially provided by firing experiments in the field and in the laboratory (for detailed information, see Wagner [ed] 2003). Laboratory experiments conducted in artificial settings typically allow a tighter control and more precise measurements of relevant variables than field experiments. At the same time, field experiments permit the observation of operation of the firing structure and associated human behavior in realistic working conditions. Clearly, these two kinds of experiments are complementary. Field experiments should be conducted repeatedly to refine them and acquire reliable data (Tringham 1978; Schiffer and Skibo 1987; Wagner et al. 1998; Shimada 2005; Shimada et al. 1998, 2003a;).

Laboratory firing and re-firing experiments of Huaca Sialupe ceramic and clay samples (both locally available clays and excavated, prepared clay mixtures) as well as their Mössbauer spectroscopic analysis (hereafter MSA) were conducted in the Department of Physics at the München Technical University in Germany. MSA allows us to "gain information on the original firing conditions [of pottery] and hence on the techniques and skills of the ancient potters" (Wagner and Kyek 2004: 5). It is based on the simple facts that the changes which pottery clays "undergo during firing are reflected in the Mössbauer spectra of the fired ceramics" (Wagner and Kyek 2004: 5; for detailed information, see Wagner (ed) 2003, 2004).

Field firing experiments were conducted near the site of Huaca Sialupe using a full-size replica kiln and 25 replica vessels prepared by J. Sosa (Fig. 12; Goldstein and Shimada 2007, 2010; Shimada et al. 2003a, 2007). The kiln and vessels, as far as possible, replicated those of the Middle Sicán era excavated at the site. For both our experiments the principal fuel was locally available, dried and broken algarrobo (Prosopis pallida; Goldstein and Shimada 2010; Shimada et al. 2003a). Dried leaves and tiny branches of the same tree and other indigenous plants were used in the initial stage of firing. Additionally, we used dried cow dung (local) and llama dung (brought in from Callejón de Huáylas) as a fuel and the source of carbon in the reducing firing stage. Changing temperatures in various parts of the kiln during the entire firing process were measured by means of five nickle/nickle-chromium $(\mathrm{Ni} / \mathrm{Ni}-\mathrm{Cr})$ thermocouples each connected to a digital temperature-meter (Fig. 12).

Our experiments demonstrated that the Middle Sicán semi-closed kilns are simple to build, durable, and easy to manipulate to achieve desired firing conditions and temperatures. The narrow opening along the top of the kiln allows for efficient loading of vessels and fuels while reducing the 
Figure 12. A view of our ceramic firing experiment conducted in 2000 with participation of an archaeologist (I. Shimada), a potter (J. Sosa), a chemist with experience in archaeometry (U. Wagner), a paleoethnobotanist (D. J. Goldstein), and an illustrator (C. Samillán). J. Sosa, who took charge of ceramic firing, stands next to the kiln. Black bottles and bowls that were successfully fired in one of our firing experiments are seen in the foreground. Black wires in the foreground connected the thermocouples placed at various parts of the kiln to digital thermometers (Photo by Izumi Shimada).

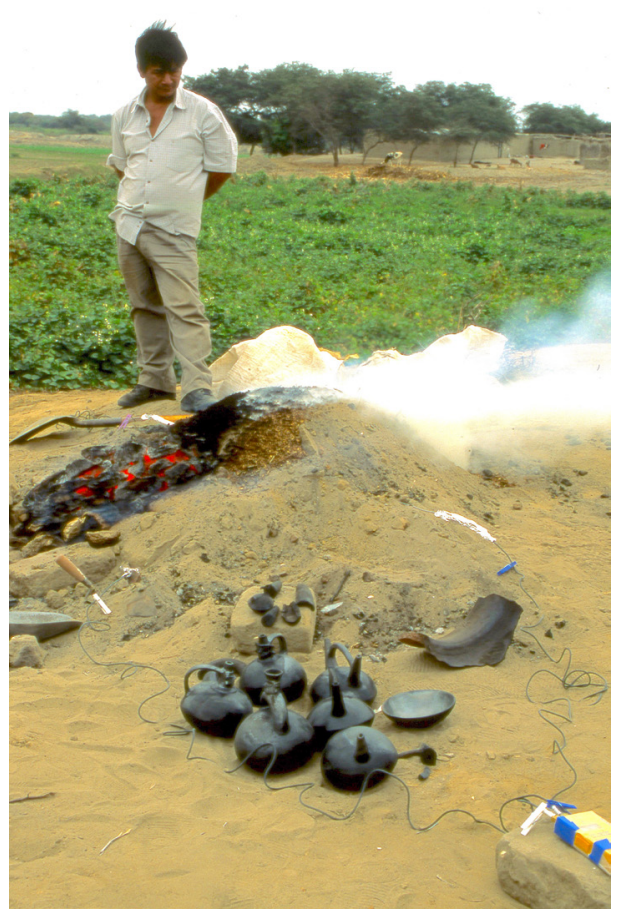

difficulty of building and supporting a complete dome. Depending on the desired atmospheric conditions and/or temperatures of the firing chamber, the opening can be adjusted with movable lids (e.g., large sherds), which can be stabilized and sealed by applying mud mortar. Though the relatively small size of the firing chamber would have limited the number of vessels that could have been fired at one time (about a dozen or fewer single-spout bottles), the presence of multiple kilns meant that an appreciable number of vessels could have been fired at a time. The small size would have allowed control over the firing conditions, the coloration of the pottery and reduced the risk of firing mishaps. Our firing experiments indeed support these expectations. At Huaca Sialupe and Pomac Canal (ca. 1000 BC to AD 350), where many of this type of kiln were used, we found no large waster piles (Shimada et al. 1994, 1998) as have been reported at the Moche ceramic production center of Cerro Mayal in the Chicama Valley (Russell et al. 1998).

Mössbauer spectra of the samples of excavated Middle Sicán black pottery and those of modern replica vessels fired in our field experiments compare very well and allow us to tentatively characterize the firing process necessary to produce the black finish for which the Middle Sicán ceramics are justly known (Shimada and Wagner 2001; Shimada et al. 2003b,d).

It is evident that the characteristic permanent and truly black finish of the Middle Sicán fine pottery was produced through effective control of the firing atmosphere and temperature (Shimada and Wagner 2001; Shimada et al. 2003a; Wagner et al. 2005); it did not involve the use of a special iron-rich slip, the mixing of graphite in the clay, or manganese oxide-based black paint that were documented elsewhere. The shiny, truly black appearance of Middle Sicán pottery is the result of even and thorough carbon deposition from the pyrolysis of organic compounds (soot) on its well-burnished surface with penetration to a depth of a few millimeters. In comparison, what archaeologists often inappropriately call black pottery has, in reality, a gray color that resulted from reduction of iron silicates in the clay mixture used for its manufacture; carbon is not needed to achieve the gray color. 
It is also apparent that the high temperature in the firing chamber of the kiln as well as the fine and even clay particle size of the paste (see below) and the high degree of surface burnishing are critical for achieving the best finish. Ideally, a carbon source such as dried llama dung, plant leaves (fresh or dried) should be charged into the kiln at a late stage of the firing process ${ }^{1}$. MSA has shown that Middle Sicán blackware was first fired under oxidizing conditions before reduction took place. In some cases, it appears that kilns were opened prematurely while they were still relatively hot, resulting in a partial oxidation of the fired vessels. In our field experiments, a good black color was obtained when dung or leaves were charged into the kiln 200-300 minutes after the onset of firing, when the temperature had risen to $800-900^{\circ} \mathrm{C}$ and the firing chamber contained ample burning fuels to retain the high temperature. Without recourse to a thermometer, the ancient potter may gauge the internal kiln temperature, as José Sosa did in our field experiments, by monitoring the color and hardness of mud placed around the kiln to seal it and/or how fast an organic substance (dried cow or llama dung) placed atop the kiln burns.

TSP and scanning electron microscopy showed the fine and even clay paste particle size of truly black sherds - most likely resulting from the levigation described earlier. They also showed that the carbon was not only deposited on the surface to form a smooth layer, but that it also penetrated a few millimeters into the body of the ceramics, accounting for the uniform and truly black coloration. Thin-sections of Sicán red-and-black ware exhibit a fine texture containing inclusions with grain sizes around $0.1 \mathrm{~mm}$. The deposition of the smooth carbon layer was facilitated by a thorough burnishing of the surface of the vessel together with the formation of graphite crystals on the surface through prolonged exposure of the carbon to temperatures of ca. $900^{\circ} \mathrm{C}$ or higher. These features and steps together resulted in the metallic sheen of the Sicán blackware (Shimada and Wagner 2001).

Sherds from the seaside Chimú settlement of Puerto Pobre located nearly 400 kilometers south of Huaca Sialupe in the Casma Valley were analyzed and compared with the Sicán blackware. Not surprisingly, the trace element contents of these two types of pottery, as determined by NAA are quite different. TSP also revealed that their pastes are completely different and coarser; the Puerto Pobre sherd has a dense micaceous matrix with 1-2 milimeters inclusions (mostly quartz, plagioclase and fragments of various types of rock), amounting to ca. $20 \%$ of the volume. Mössbauer spectra of the Chimú sherds, on the other hand, do not differ much from the those of Sicán blackware, indicating that it was generally fired at temperatures between 800 and $900^{\circ} \mathrm{C}$ under strongly reducing conditions. Here NAA and TSP, which depend on the raw materials used, are more conclusive for characterization of the material than MSA which mainly describes firing conditions (Shimada et al. 2003b).

Additional comparative insights come from archaeometric analyses (NAA, TSP, XRD, and MSA) of mold-made ceramics from the Chimú workshop at Pampa de Burros on the north bank of the Lambayeque valley (Tschauner 2001, 2014; Tschauner and Wagner 2003; Wagner et al. 2014). The excavation and analysis revealed that they were made with local clay and fired at 700 to $850^{\circ} \mathrm{C}$ in under strongly reducing conditions with partial re-oxidation at the end of the firing in simple "pit kilns" (e.g., without any permanent side walls or superstructures). The observed variation in firing quality of the Chimú ceramics and their Mössbauer spectra are likely to relate to the constraints of firing in pit kilns.

Like those of Puerto Pobre, Chimú ceramics from Pampa de Burros do not have fine paste, the degree of polish, and even blackness that characterize the earlier Middle Sicán black ceramics, including those produced at Huaca Sialupe. It is evident that less effort and care were invested in making Chimu "black pottery" than in those of the Middle Sicán. Tschauner and Wagner (2003: 184) conclude that ceramic production in the Lambayeque region under Chimú rule emphasized standardization, uniformity, rapidity, and quantity over quality; ceramics no longer served as status symbol. 


\section{Conclusion: A holistic understanding of the Middle Sicán blackware production}

The Middle Sicán technology for producing black pottery was evolutionary and not revolutionary in character as it was preceded by various, though brief, periods when truly black and so-called "black" pottery was produced in limited quantities. Kilns resembling the Middle Sicán kilns that were efficient and semi-closed, already existed by ca. 1000 B.C. in the La Leche valley (Shimada $e t$ al. 1994, 1998). The Middle Sicán legacy is the refinement and perfection of a long-standing firing technology, while it enabled the Middle Sican potters to produce truly black pottery consistently and on a large scale. We suspect the widespread and persistent popularity of black pottery during the Late Intermediate Period and the Late Horizon along much of the Peruvian coast was due to an effort to emulate the artistic and technical qualities of the Middle Sicán black bottles that had spread there earlier (Segura and Shimada 2014). We infer that the prestige of the Middle Sicán religion and its art together with the lustrous, truly black appearance of the pottery that had been rarely seen before played an important role in establishing the popularity of black pottery (Segura and Shimada 2014).

If the Sicán black pottery technology was an evolutionary outgrowth of an existing technology, what factors contributed it to be perfected with large scale production? A broader understanding of the Sicán culture is crucial for answering this question. As documented elsewhere (e.g., Shimada and Griffin 1994; Shimada 1994a,c, 1995, 2014; Gordus and Shimada 1995; Shimada et al. 1999, 2000), the Middle Sicán culture is distinguished among pre-Hispanic cultures for its unprecedented production of precious metal sheets containing varying concentrations (anything from 18 to merely 1 or 2 karats) of gold along with silver and copper. These sheets were shaped to produce diverse ornaments and ritual paraphernalia as well as a veneer over ceramic and wooden objects and line painted cloth. In spite of its impressive productive output, precious metal products were nonetheless restricted to a relatively small number of social elites.

Based on our prior holistic study of Middle Sicán metallurgy, we argue that the restricted access to and the greater social and symbolic value of precious metals underlay the drive to produce lustrous black pottery that approximated the appearance of the more prestigious precious metal vessels (Cleland and Shimada 1992, 1994, 1998; Shimada and Wagner 2007). In this respect, it is important to note that, precious metal objects with low gold contents, acquire a blackish tarnish over time without regular polishing and then look much like black pottery. Black pottery was available to both elites and non-elites and used primarily in ritual and funerary contexts. In addition, both black and redware Middle Sicán pottery show features such as a meridian line or ledge on the spherical body of the bottle that have no apparent functions but match in appearance specific structural features on precious metal vessels (Cleland and Shimada 1992, 1994, 1998) ${ }^{2}$. In general, the religious iconography on ceramic vessels represents simplified versions of what appears on the precious metal counterparts. The situation described here may be a case in which technological progress was promoted by symbolic and social factors.

It remains a future task to ascertain whether there were economic, environmental and/or technical factors (e.g., competition for high quality fuels between potters and metalworkers; Goldstein and Shimada 2007, 2010; Shimada et al. 2007) that also contributed to the improvement and the popularity of blackware. A larger question is how the inferred relationship between Middle Sicán social values and symbolism, on the one hand, and technological progress, on the other, compares with the rationale and causal processes of blackware production in other time periods and areas. This question must await additional systematic studies. For the time being, building on data and insights gained from our holistic study of the well-preserved workshop at Huaca Sialupe, we have reconstructed much of the entire chaîne opératoire and illuminated many of critical technological choices, as well as social and symbolic factors that contributed to the refinement and intensification of Middle Sicán black pottery production. 


\section{Notes}

${ }^{1}$ The kiln must be tightly sealed to retain the high temperature and, at the same time, create and maintain a reducing atmosphere.

${ }^{2}$ Middle Sicán vessels made with precious sheetmetal were often formed from two halves joined by a clearly visible seam.

\section{Acknowledgements}

Fieldwork at Huaca Sialupe was supported by generous grants made to I. Shimada from the John Heinz III Fund (1999), the National Geographic Society (1999, 2001), and the WennerGren Foundation (2001). The analysis of materials excavated in Peru in 2000 was made possible by a Southern Illinois University Faculty Research Grant to I. Shimada. Analysis of ceramic and clay samples in Germany was made possible by a grant to U. Wagner by the Deutsche Forschungsgemeinschaft. We also thank D. L. Goldstein, G. Matsumoto, J. A. Montenegro C., Rospigliosi, C. Samillán, M. J. Shimada, J. Sosa, and S. Taylor for their assistance in field and laboratory work. We also benefitted from comments on an earlier version from two anonymous reviewers and J. F. Merkel. M. Shimada provided helpful editorial comments. Lastly, we thank the co-editors of this volume, Isabelle Druc and Jalh Dulanto for their invitation to contribute to this issue.

\section{REFERENCES}

Acevedo, V. J., M. A. López, E. Freire, E. B. Halac, G. Polla and M. Reinoso (2012). Estudio de pigmentos en alfarería estilo negro sobre rojo de Quebrada de Humahuaca, Jujuy, Argentina, Boletín del Museo Chileno de Arte Precolombino 17(2), 39-51. https://doi.org/10.4067/S0718-68942012000200004

Arnold, D. E. (1972). Mineralogical analyses of ceramic materials from Quinua, Department of Ayacucho, Peru, Archaeometry 14, 93-101. https://doi.org/10.1111/j.1475-4754.1972.tb00053.x

Arnold, D. E. (2003). Ecology and ceramic production in an Andean community, Cambridge University Press, Cambridge.

Bankes, G. H. (1985). The manufacture and circulation of paddle and anvil pottery on the North Coast of Peru, World Archaeology 17, 269-277. https://doi.org/10.1080/00438243.1985.9979967

Bushnell, G. H. S. (1957). Peru, Frederick A. Praeger, New York.

Carmichael, P. H. (1990). Nazca pottery construction, Nawpa Pacha 24, 31-48. https://doi.org/10.1179/ naw. 1986.24.1.002

Centeno, S.A., V. Williams, N.C. Little, and R.J. Speakman (2012). Characterization of surface decorations in prehispanic archaeological ceramics by Raman spectroscopy, FTIR, XRD and XRF, Vibrational Spectroscopy 58, 119-124. https://doi.org/10.1016/j.vibspec.2011.11.004

Cleland, K. M. and I. Shimada (1992). Sicán bottles: Marking time in the Peruvian Bronze Age, Andean Past 3 , 193-235.

Cleland, K. M. and I. Shimada (1994). Cerámica paleteada: Tecnología, modos de producción y aspectos sociales, in: I. Shimada (ed.), La tecnología y la organización de producción de las cerámicas en los Andes prehispánicos, 321-348, Fondo Editorial PUCP, Lima.

Cleland, K. M. and I. Shimada (1998). Paleteada pottery: Technology, chronology and sub-culture, in: I. Shimada (ed.), Andean ceramics: Technology, organization and approaches, 111-150, MASCA Research Papers, University Museum of Archaeology and Anthropology, University of Pennsylvania, Philadelphia.

Collier, D. (1959). Pottery stamping and molding on the North Coast of Peru, Actas del 33 Congreso Internacional de Americanistas 2, 421-431.

Costin, C. L. (1991). Craft specialization: Issues in defining, documenting, and explaining the organization of production, in: M. Schiffer (ed.), Archaeological method and theory, vol. 3, 1-56, University of Arizona Press, Tucson.

Costin, C. L. (2000). The use of ethnoarchaeology for the archaeological study of ceramic production, Journal of Archaeological Method and Theory 7(4), 377-403. 
Costin, C. L. (2001). Craft production systems, in: G. Feinman and T. Douglas Price (eds.), Archaeology at the millennium: A sourcebook, 273-327, Kluwer Academic/Plenum Publishers, New York.

Costin, C. L., and M. Hagstrum (1995). Standardization, labor investment, skill, and the organization of ceramic production in Late Prehispanic Peru, American Antiquity 60, 619-639. https://doi.org/10.2307/282046

Craig, A. K. and I. Shimada (1986). El Niño flood deposits of Batán Grande, Northern Peru, Geoarchaeology: An International Journal 1(1), 29-38. https://doi.org/10.1002/gea.3340010104

Cresswell, R. (1976). Avant-Propos, Techniques et Culture 1, 5-6.

De La Fuente, G. and J. M. Pérez Martínez (2018). Ancient potters, paintings and craft specialization in Northwestern Argentine Region: New data through Raman characterization of pre- and postfiring ceramic paintings on Aguada Portezuelo ceramics from Middle Period (Catamarca, Argentina), Archaeological and Anthropological Sciences (2018), 1-16. Springer Online. https://doi.org/10.1007/s12520-018-0676-9. https://doi.org/10.1007/s12520-018-0676-9

de Lavalle, J. A. (editor) (1988). Chimú, Arte y Tesoros del Perú, Banco de Crédito del Perú, Lima.

Digby, A. (1948). Radiographic examination of Peruvian pottery techniques, Actes du XXVIIIème Congrès International des Américanites, Paris 1947, 605-608, Paris.

Donnan, C. B. (1965). Moche ceramic technology, Nawpa Pacha 3, 115-138. https://doi.org/10.1179/ naw.1965.3.1.004

Donnan, C. B. (1992). Ceramics of ancient Peru, Fowler Museum of Cultural History, University of California, Los Angeles.

Druc, I. (2013). What is local? Looking at ceramic production in the Peruvian highlands and beyond, Journal of Anthropological Research 69(4), 485-513. https://doi.org/10.3998/jar.0521004.0069.404

Fernández, M., and L. A. Sánchez (2014). Un taller alfarero del periodo Lambayeque Medio en Huaca La Pava: producción y tecnología, in: J. C. Fernández and C. A. Wester (eds.), Cultura Lambayeque en el contexto de la costa norte del Perú, Coloquio II, 311-327, EMDECOSEGE S.A., Chiclayo.

Gallardo, F., I. Correa, G. Pimentel and J. F. Blanco (2017). Consumption consumes: Circulation, exchange, and value of San Pedro de Atacama black polished ceramics, Latin American Antiquity 28(2), 252-268. https://doi. org/10.1017/laq.2017.15

Goldstein, D. J. and I. Shimada (2007). Middle Sicán multi-craft production: Resource management and labor organization, in: I. Shimada (ed.), Craft production in complex societies: Multicraft and producer perspectives, 44-67, The University of Utah Press, Salt Lake City.

Goldstein, D. J. and I. Shimada (2010). Feeding the fire: food, metal, and ceramic production in the Middle Sicán period (950-1050 C.E.), in: L. Klarich (ed.) From subsistence to social strategies: Refining the material correlates of household and suprahousehold levels of food preparation, 161-189, University of Colorado Press, Boulder.

Gordus, A. and I. Shimada (1995). Neutron activation analysis of microgram samples from 364 gold objects from a Sicán burial site in Peru, in: P. B. Vandiver, J. R. Druzik and J. L. Galvan (comp.), Materials issues in art and archaeology IV, 127-142, Materials Research Society Symposium Proceedings, vol. 352.

Klaus, H. (2003). Life and death at Huaca Sialupe: The mortuary archaeology of a Middle Sicán community, North Coast of Peru, MA thesis, Department of Anthropology, Southern Illinois University, Carbondale.

Klaus, H. and I. Shimada (2003). Reflections of identity: Death and burial in pre-Hispanic Middle Sicán society, North Coast of Peru, paper presented at the $80^{\text {th }}$ Annual Meeting of the Central States Anthropological Society, Louisville.

Larco, R. (1963). Las épocas peruanas, Santiago Valverde, Lima.

Larco, R. (1966). Peru, Frederick Miller, London.

Lemonnier, P. (1992). Elements for an anthropology of technology, University of Michigan Museum of Anthropology, Ann Arbor.

Lemonnier, P. (1993). Introduction, in: P. Lemonnier (ed.), Technological choices: Transformation in material cultures since the neolithic, 1-35, Routledge, London/New York.

Leroi-Gourhan, A. (1993). Gesture and Speech, MIT Press, Cambridge.

Lyon, P. J. (1991). Andean art and its cultural implications, in: S. Masuda and I. Shimada (eds.)_Ancient art of the Andean world, 27-45, Iwanami Shoten, Publishers, Tokyo.

Maniatis, Y., E. Aloupi y A. D. Stalios (1993). New evidence for the nature of the black Attic gloss, Archaeometry 35, 23-34. https://doi.org/10.1111/j.1475-4754.1993.tb01021.x

Maquet, J. (1979). Aesthetic anthropology, Undena, Malibu.

Maquet, J. (1985). The aesthetic experience: An anthropologist looks at the visual art, Yale University Press, New Haven. 
Mohr, K. (1984-1985). Traditional pottery of Raqch'I, Cuzco, Peru: A preliminary study of its production, distribution, and consumption, Nawpa Pacha 22-23, 161-210. https://doi.org/10.1179/naw.1984.22-23.1.005

Pozzi-Escot, D., M. Alarcón and C. Vivanco (1998). Wari ceramics and production technology: The view from Ayacucho, in: I. Shimada (ed.) Andean ceramics: Technology, organization and approaches, 253-281, MASCA Research Papers, University Museum of Archaeology and Anthropology, University of Pennsylvania, Philadelphia.

Puente, V., D. Mariela, J. P. Tomba and J. M. Porto (2017). Compositional variability of pigments of Belén-style prehispanic ceramics from El Bolsón valley, Catamarca province, Argentina, Journal of Archaeological Science: Reports 12, 553-560. https://doi.org/10.1016/j.jasrep.2017.03.007

Purin, S. (1983). Utilisation des Rayons-X pour l'Observation des Traces de Fabrication sur Cinq Vases Mochicas, Bulletin des Musées Royaux d'Art et d'Histoire 54(2), 5-20.

Purin, S. (1985). Construction de Trois Vases Noirs Mochicas, Bulletin des Musées Royaux d'Art et d'Histoire 56 (1), 95-104.

Ravines, R. and F. Villiger (editors) (1989). La cerámica tradicional del Perú, Editorial Los Pinos, Lima.

Reina, R. E. and R. M. Hill II (1978). The traditional pottery of Guatemala, University of Texas Press, Austin.

Rice, P. M. (1987). Pottery analysis, a source book, University of Chicago Press, Chicago.

Rospigliosi, C. (2007). Ceramic production and state control: A view from a hinterland Middle Sicán ceramic workshop, paper presented at the $35^{\text {th }}$ Annual Meeting of the Midwest Conference of Andean and Amazonian Archaeology and Ethnohistory, Carbondale.

Russell, G. S., L. Banks L., and J. Briceño (1998). The Cerro Mayal workshop: Addressing issues of craft specialization in Moche society, in: I. Shimada (ed.) Andean ceramics: Technology, organization and approaches, 63-8, MASCA Research Papers, University Museum of Archaeology and Anthropology, University of Pennsylvania, Philadelphia.

Schaedel, R. P. (1979). The confluence of the pressedware and paddle ware traditions in coastal Peru, in: R. Hartmann and U. Oberem (eds.), Estudios americanistas II: Homenaje a H. Trimborn, 231-239, St. Augustin.

Schiffer, M. B., and J. M. Skibo (1987). Theory and experiment in the study of technological change, Current Anthropology 28, 595-622. https://doi.org/10.1086/203601

Schjellerup, I. (1986). Chimu pottery in the department of ethnography, Corpus Antiquitatum Americanensium, the National Museum of Denmark, Copenhagen.

Segura, R. A. and I.Shimada (2014). La interacción Sicán Medio-costa central, hacia 1000 d.C, in: I. Shimada (ed.), Cultura Sicán: Esplendor preinca de la costa norte [translated by G. Cervantes], 303-322, Editorial del Congreso de Perú, Lima.

Sellet, F. (1993). Chaîne opératoire: The concept and its application, Lithic Technology 18, 106-112. https://doi.org/ 10.1080/01977261.1993.11720900

Shimada, I. (1976). Socioeconomic organization at Moche V Pampa Grande, Peru: Prelude to a major transformation to come, Ph. D. dissertation, Department of Anthropology, University of Arizona, Tucson.

Shimada, I. (1981). The Batán Grande-La Leche archaeological project: The first two seasons, Journal of Field Archaeology 8, 405-446. https://doi.org/10.1179/009346981791504815

Shimada, I. (1990). Cultural continuities and discontinuities on the northern North Coast, Middle-Late Horizons, in: M. E. Moseley and A. Cordy-Collins (eds.), The northern dynasties: Kingship and statecraft in Chimor, 297-392, Dumbarton Oaks, Washington, D.C.

Shimada, I. (1994a). Pampa Grande and the Mochica Culture, University of Texas Press, Austin.

Shimada, I. (1994b). The role of metals in Middle Sicán society, in: G. Burenhult (ed.), The illustrated encyclopedia of humankind, Vol. 4: New World and Pacific civilizations, 94-95, Weldon Owen Pty Limited, Sydney.

Shimada, I. (1994c). Prehispanic metallurgy and mining in the Andes, in: A. Craig and R. West (eds.), In quest of mineral wealth: Aboriginal and colonial mining and metallurgy in Spanish America, 37-73, Louisiana State University, Baton Rouge.

Shimada, I. (1995). Cultura Sicán: Dios, riqueza y poder en la costa norte del Perú, Edu-Banco Continental, Lima.

Shimada, I. (1997). The variability and evolution of prehispanic kilns on the Peruvian coast, in: P. Rice (ed.), Prehistory and history of ceramic kilns, 103-127, Ceramics and Civilization series, American Ceramic Society.

Shimada, I. (1999). Technological developments and fuel competition: Cross-craft interaction on coastal Peru, Paper presented at the $64^{\text {th }}$ Annual Meeting of the Society for American Archaeology, Chicago.

Shimada, I. (2000). Late prehispanic coastal states, in: L. Laurencich Minelli (ed.), The Inca world: The development of pre-Columbian Peru, A.D. 1000-1534, 49-110, University of Oklahoma Press, Norman.

Shimada, I. (2005). Experimental archaeology, in: H. Maschner and C. Chippindale (eds.), Handbook of archaeological methods, vol. I, 603-642, AltaMira Press, Lanham. 
Shimada, I. (2007). Introduction, in: I. Shimada (ed.), Craft production in complex societies: Multi-crafting, sequential production, and producers, 1-21, University of Utah Press, Salt Lake City.

Shimada, I. (2014). Detrás de la máscara de oro: la Cultura Sicán, in: I. Shimada (ed.), Cultura Sicán: esplendor preinca de la costa norte [translated by G. Cervantes], 15-90, Editorial del Congreso de Perú, Lima.

Shimada, I. (2019). Early Horizon Cupisnique ceramic production in Pomac, North Coast of Peru: The role of archeometry in its holistic understanding, in: M. D. Glascock, H. Neff and K.J. Vaughn (eds.), Ceramics of the indigenous cultures of South America: Studies of production and exchange through compositional analysis, 55-58, University of New Mexico Press, Albuquerque.

Shimada, I. (ed.) (1994). La tecnología y la organización de producción de las cerámicas en los Andes prehispánicos, Fondo Editorial PUCP, Lima.

Shimada, I. (ed.) (1998). Andean ceramics: Technology, organization and approaches, MASCA Research Papers, University Museum of Archaeology and Anthropology, University of Pennsylvania, Philadelphia.

Shimada, I. (ed.) (2007). Craft production in complex societies: Multi-crafting, sequential production, and producers, University of Utah Press, Salt Lake City.

Shimada, I., V. Chang, C. Elera, H. Neff, M. Glascock, U. Wagner and G. Rupert (1994). Los hornos y la producción de cerámica Formativa en Batán Grande, costa norte del Perú, in: I. Shimada (ed.), La tecnología y la organización de producción de las cerámicas en los Andes prehispánicos, 67-119, Fondo Editorial PUCP, Lima.

Shimada, I., V. Chang, D. Killick, H. Neff, M. Glascock, U. Wagner and R. Gebhard (1998). Formative ceramic kilns and production in Batán Grande, north coast of Peru, in: I. Shimada (ed.), Andean ceramics: Technology, organization and approaches, 23-61, MASCA Research Papers, University Museum of Archaeology and Anthropology, University of Pennsylvania, Philadelphia.

Shimada, I. and A. K. Craig (2013). The Style, technology and organization of Sicán mining and metallurgy, northern Peru: Insights from holistic study, Chungara, Revista de Antropologia Chilena 45(1), 3-31.

Shimada, I., D. Goldstein, W. Häusler, J. Sosa and U. Wagner (2003a). Early pottery making in northern coastal Peru: Part II: Field firing experiments, in: U. Wagner (ed.), Mössbauer spectroscopy in archaeology, 91-105, Hyperfine Interactions 150(1-4), Kluwer Publishing, New York. https://doi.org/10.1023/ B:HYPE.0000007356.66809.26

Shimada, I., D. Goldstein, U. Wagner and A. Bezúr (2007). Pre-Hispanic Sicán furnaces and metalworking: Toward a holistic understanding, in: R. Lleras Pérez (ed.), Metalurgia en la América antigua: teoría, arqueología, simbología y tecnología de los metales prehispánicos, 337-361, Travaux de l'Institut Français d'Études Andines 253, Fundación de Investigaciones Arqueológicas Nacionales/Banco de la República Bogotá/Instituto Francés de Estudios Andinos, Lima.

Shimada, I., A. Gordus and J. A. Griffin (2000). Technology, iconography, and significance of metals: A multi-dimensional analysis of Middle Sicán objects, in: C. McEwan (ed.), Pre-Columbian gold: Technology, iconography, and style, 28-61, The British Museum Press, London.

Shimada, I., A. Gordus, J. A. Griffin and J. Merkel (1999). Sicán alloying, working and use of precious metals: An interdisciplinary perspective, in: S. M. Young, A. M. Pollard, P. Budd and R. A. Ixer (eds.), Metal in antiquity, 301-309, BAR International Series 792, Archaeopress, Oxford.

Shimada, I. and J. A. Griffin (1994). Precious metal objects of the Middle Sicán, Scientific American 270(4), 60-67.

Shimada, I., W. Häusler, T. Hutzelmann, J. Riederer and U. Wagner (2003b). Early pottery making in northern coastal Peru: Part III: Mössbauer study of Sicán pottery, in: U. Wagner (ed.), Mössbauer spectroscopy in archaeology, 107-123, Hyperfine Interactions 150(1-4), Kluwer Publishing, New York. https://doi.org/10.1023/ B:HYPE.0000007381.73578.b3

Shimada, I., W. Häusler, T. Hutzelmann and U. Wagner (2003c). Early pottery making in northern coastal Peru: Part I: Mössbauer study of clay, in: U. Wagner (ed.), Mössbauer spectroscopy in archaeology, 73-89, Hyperfine Interactions 150 (1-4), Kluwer Publishing, New York. https://doi.org/10.1023/B:HYPE.0000007355.08293.69

Shimada, I., W. Häusler, J. A. Jakob, M. Montenegro, J. Riederer and U. Wagner (2003d). Early pottery making in northern coastal Peru: Part IV: Mössbauer study of pottery from Huaca Sialupe, in: U. Wagner (ed.), Mössbauer spectroscopy in archaeology, 125-139, Hyperfine Interactions 150(1-4), Kluwer Publishing, New York. https://doi.org/10.1023/B:HYPE.0000007354.42840.ef

Shimada, I. and J. F. Merkel (1987). Sicán metallurgy: Holistic understanding and the role of archaeometry, Paper presented at the 52nd Annual Meeting of the Society for American Archaeology, Toronto.

Shimada, I. and J. F. Merkel (1991). Copper alloy metallurgy in ancient Peru, Scientific American 265(1), 80-86. https://doi.org/10.1038/scientificamerican0791-80

Shimada, I., J. F. Merkel, A. Szumilewicz and E. Napa (2018). Ampliando nuestra comprensión holística de la metalurgia Sicán: excavación de un taller de oro en Huaca Loro, Perú, Actas del II Congreso Nacional de Arqueología, vol. I, 42-51, Ministerio de Cultura del Perú, Lima. 
Shimada, I. and U. Wagner (2001). Peruvian black pottery production and metal working: A Middle Sicán craft workshop at Huaca Sialupe, Materials Research Society Bulletin 26(1), 25-30, Materials Research Society, Warrendale. https://doi.org/10.1557/mrs2001.15

Shimada, I. and U. Wagner (2007). Craft production on the pre-Hispanic north coast of Peru: A holistic approach and its results, in: J. Skibo, M. Grave and M. Stark (eds.), Archaeology as anthropology: Theoretical and methodological approaches, 163-197, University of Arizona Press, Tucson.

Sillar, B. (ed.) (2000). Shaping culture: Making pots and constructing households. An ethnoarchaeological study of pottery production, trade and use in the Andes, British Archaeological Reports International Series, 883, Oxford.

Stark, M. T. (2003). Current issues in ceramic ethnoarchaeology, Journal of Archaeological Research 11(3), 193-242.

Stone-Miller, R. (1995). Arts of the Andes from Chavin to Inca, Thames and Hudson, London.

Stumer, L. M. (1957). Céramica negra del estilo Maranga, Revista del Museo Nacional 26, 272-289. Lima.

Taylor, S. R. (2002). Artisan autonomy in the Middle Sicán State: Variability in mold-made ceramic production, MA thesis, Department of Anthropology, Southern Illinois University, Carbondale.

Taylor, S. R. and I. Shimada (2001). Variability in mold-made Sicán ceramics: A multi-dimensional perspective from a workshop at Huaca Sialupe, poster presented at the 66th Annual Meeting of the Society for American Archaeology, New Orleans.

Tello, J. C. (1938). Arte antiguo peruano: álbum fotográfico de las principales especies arqueológicas de cerámica Muchik existentes en los museos de lima, primera parte: tecnología y morfología. Inca 2: VII-LXII, 1-280. Lima.

Tringham, R. (1978). Experimentation, ethnoarchaeology, and the leapfrogs in archaeological methodology, in: R. A. Gould (ed.), Explorations in ethnoarchaeology, 169-199, University of New Mexico Press, Albuquerque.

Tschauner, H. (2001). Socioeconomic and political organization in the late prehispanic Lambayeque sphere, North Coast of Peru, Ph. D. dissertation, Harvard University, Cambridge.

Tschauner, H. (2014). Los Sicán bajo el dominio Chimú, in: I. Shimada (ed.), Cultura Sicán: esplendor preinca de la costa norte [translated by G. Cervantes], 341-360, Editorial del Congreso de Perú, Lima.

Tschauner, H. and U. Wagner (2003). Pottery from a Chimú workshop studied by Mössbauer spectroscopy, in: U. Wagner (ed.), Mössbauer spectroscopy in archaeology, 165-186, Hyperfine Interactions 150(1-4), Kluwer Publishing, New York. https://doi.org/10.1023/B:HYPE.0000007173.11484.7a

von Hagen, V. (1964). The desert kingdoms of Peru, New York Graphic Society, Greenwich.

Wagner, F. E. and A. Kyek (2004). Mössbauer spectroscopy in archaeology: Introduction and experimental considerations, in: U. Wagner (ed.), Mössbauer spectroscopy in archaeology, 5-33, Hyperfine Interactions 154(1-4), Kluwer Publishing, New York. https://doi.org/10.1023/B:HYPE.0000032112.94624.95

Wagner, U. (ed.) (2003). Mössbauer spectroscopy in archaeology, vol. II, Kluwer Publishing, New York.

Wagner, U., R. Gebhard, J. Froh, W. Haeusler, I. Shimada and F. Wagner (2005). A Mössbauer study of different types of black pottery, poster presented at the International Conference on the Application of the Mössbauer Effect (ICAME 2005), Montpellier.

Wagner, U., R. Gebhard, R. Murad, J. Riederer, I. Shimada and F. E. Wagner (1998). Production of Formative ceramics: Assessment by physical methods, in: I. Shimada (ed.), Andean ceramics: Technology, organization and approaches, 173-197, MASCA Research Papers, University Museum of Archaeology and Anthropology, University of Pennsylvania, Philadelphia.

Wagner, U., F. Wagner and I. Shimada (2014). Estudio de cerámica de Sicán Medio mediante métodos físicos, in: I. Shimada (ed.), Cultura Sicán: Esplendor preinca de la costa norte, [translated by G. Cervantes], 159-166, Editorial del Congreso de Perú, Lima.

Williams, V. I. (2010). Pottery manufacture, proveniences, and pigments of pre-inca and Inca archaeological sites in southern Andes, paper presented at the $75^{\text {th }}$ Annual Meeting of the Society for American Archaeology, St. Louis.

Fecha de recepción: 5-8-2019

Fecha de aceptación: 16-12-2019 